\title{
Review \\ Phase-Change Materials in Concrete: Opportunities and Challenges for Sustainable Construction and Building Materials
}

\author{
Raju Sharma ${ }^{1}$, Jeong-Gook Jang ${ }^{1, *(\mathbb{D})}$ and Jong-Wan $\mathrm{Hu}^{2,3}$ (D) \\ 1 Division of Architecture and Urban Design, Urban Sciences Institute, Incheon National University, \\ 119 Academy-ro, Yeonsu-gu, Incheon 22012, Korea; rsharma@thapar.edu \\ 2 Department of Civil and Environmental Engineering, Incheon National University, 119 Academy-ro, \\ Yeonsu-gu, Incheon 22012, Korea; jongp24@inu.ac.kr \\ 3 Incheon Disaster Prevention Research Center, Incheon National University, 119 Academy-ro, Yeonsu-gu, \\ Incheon 22012, Korea \\ * Correspondence: jangjg@inu.ac.kr
}

check for updates

Citation: Sharma, R.; Jang, J.-G.; Hu, J.-W. Phase-Change Materials in Concrete: Opportunities and Challenges for Sustainable Construction and Building Materials. Materials 2022, 15, 335. https:// doi.org/10.3390/ma15010335

Academic Editor: Qing-feng Liu

Received: 6 December 2021

Accepted: 28 December 2021

Published: 3 January 2022

Publisher's Note: MDPI stays neutral with regard to jurisdictional claims in published maps and institutional affiliations.

Copyright: (C) 2022 by the authors. Licensee MDPI, Basel, Switzerland. This article is an open access article distributed under the terms and conditions of the Creative Commons Attribution (CC BY) license (https:// creativecommons.org/licenses/by/ $4.0 /)$.

\begin{abstract}
The use of phase-change materials (PCM) in concrete has revealed promising results in terms of clean energy storage. However, the negative impact of the interaction between PCM and concrete on the mechanical and durability properties limits field applications, leading to a shift of the research to incorporate PCM into concrete using different techniques to overcome these issues. The storage of clean energy via PCM significantly supports the UN SDG 7 target of affordable and clean energy. Therefore, the present study focuses on three aspects: PCM type, the effect of PCM on concrete properties, and connecting the outcome of PCM concrete composite to the United Nations sustainable development goals (UN SDGs). The compensation of reduction in strength of PCMcontained concrete is possible up to some extent with the use of nanomaterials and supplementary cementitious materials. As PCM-incorporated concrete is categorized a type of building material, the large-scale use of this material will affect the different stages associated with building lifetimes. Therefore, in the present study, the possible amendments of the different associated stages of building lifetimes after the use of PCM-incorporated concrete are discussed and mapped in consideration of the UN SDGs 7, 11, and 12. The current challenges in the widespread use of PCM are lower thermal conductivity, the trade-off between concrete strength and PCM, and absence of the link between the outcome of PCM-concrete composite and UN SDGs. The global prospects of PCM-incorporated concrete as part of the effort to attain the UN SDGs as studied here will motivate architects, designers, practicing engineers, and researchers to accelerate their efforts to promote the consideration of PCMcontaining concrete ultimately to attain net zero carbon emissions from building infrastructure for a sustainable future.
\end{abstract}

Keywords: phase change materials; concrete; building envelopes; carbon emission; United Nations sustainable development goals; thermal energy storage

\section{Introduction}

The building sector is one of the significant contributors across the globe to the resiliency and safe livelihoods of humans [1]. Nevertheless, the building sector consumes numerous natural resources and conventional power in every part of the world and has, therefore, been characterized as contributing to the degradation of the environment. The six largest emitters of greenhouse gases (GHG), together accounting for $62 \%$ globally, are China (26\%), the United States (13\%), the European Union (more than $8 \%$ ), India (7\%), the Russian Federation (5\%), and Japan (almost 3\%). In 2018, the largest increase in GHG emissions was reported for India $(+5.5 \%)$, followed by the United States $(+2.7 \%)$ and China $(+1.9 \%)$ [2]. An analysis of developing countries reveals greater energy demand in the 
future [3]. For instance, the international energy agency (IEA) has anticipated that by 2035, India's energy demand will have increased to $8.6 \%$ of global demand, or 1464 Mtoe [4]. Additionally, energy consumption by commercial buildings is predicted to expand at a faster rate $(8 \%)$ than that of the residential sector $(5 \%)$, and floor space is predicted to grow from 659 million square meters in 2010 to 1900 million square meters in 2030 in India [5]. However, up to 2035, China is projected to retain its share of energy consumption at around $23 \%$ out of global primary energy consumption, though after 2035 energy demand in China will gradually decline [2].

In context to global building requirements, over the next decade, more than $20 \%$ of expected global building additions up to 2050 will be built, and more than $50 \%$ of the corresponding floor area additions will occur in regions that currently do not have mandatory energy codes in place for the entire building sector [5]. The upcoming infrastructure projects can follow the design and guidelines to make a building completely energy efficient [6]. However, for the built environment (noncompliance with existing energy codes), the fields of rehabilitation and retrofitting become important. Figure 1 shows the present status of building energy codes in different countries. In the future, to evade the expensive green retrofits of buildings that are noncompliant with existing energy codes, the immediate effective implementation of building energy codes is required $[7,8]$. This is important because an absence of energy codes means users and contractors when building the infrastructure may not do so on the basis of the vision incorporated in the UN SDGs.

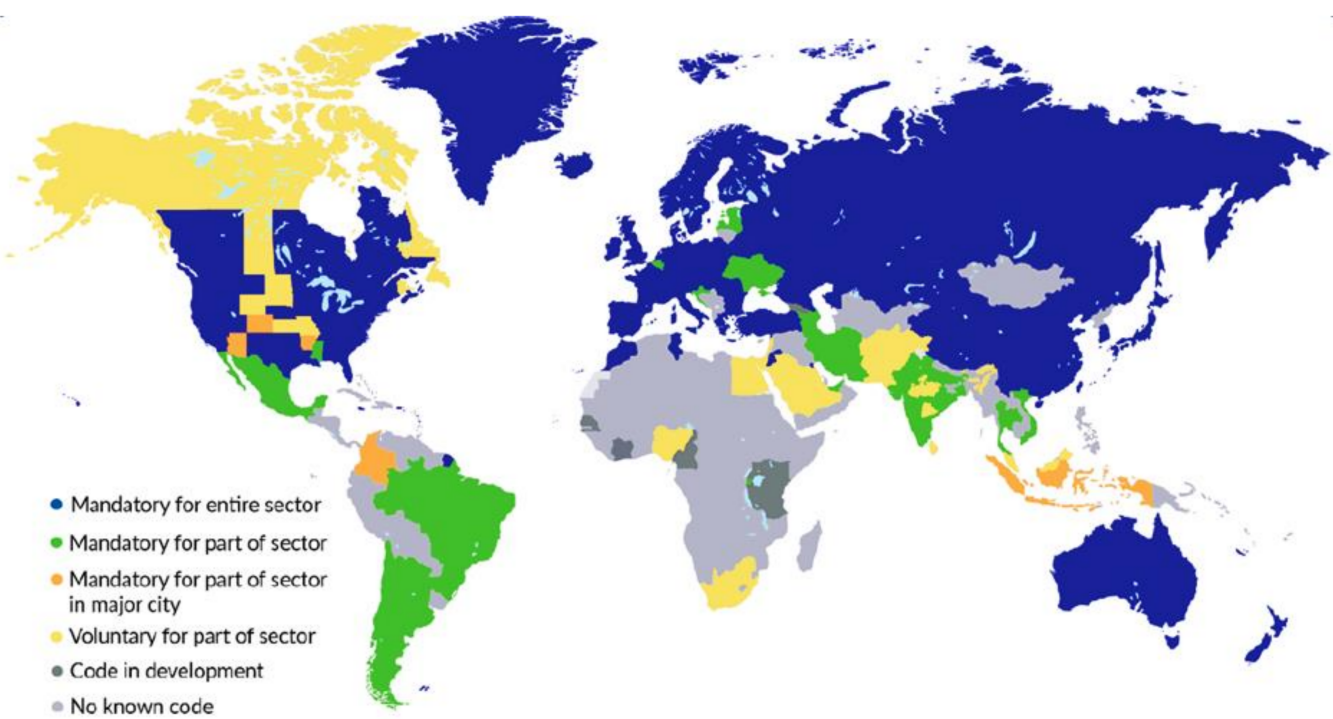

Figure 1. Building energy code by jurisdiction, 2018-19 (IEA, All right reserved) [8]. Note—this map is without prejudice the status of or sovereignty over any territory, to the delimitation of international frontiers and boundaries and to the name of any territory, city or area.

Seventeen SDGs were adopted by the UN in 2015 [9]. Particularly, UN SDGs 7 (affordable and clean energy), 9 (industry, innovation and infrastructure), 11 (sustainable cities and communities), and 12 (responsible consumption and production) are closely related to infrastructure development. Therefore, SDG intervention is a mandatory achievement for resilience and sustainability through infrastructure building [10]. The transition from fossil fuels to renewable energy to attain sustainability considering that most existing practices are based on fossil fuels is a major challenge for practitioners in the field of infrastructure development [11]. Similarly, thermal comfort (the energy demand for cooling, heating and air conditioning) in a building envelope is significantly based on the utilization of fossil fuels, and this existing practice violates the UN SDGs [12]. In the building sector, $60 \%$ of the total energy is consumed by heating, ventilation, and air conditioning (HVAC) systems for climate control $[13,14]$. Broadly, active, passive and hybrid cooling strategies facilitate indoor thermal comfort. Indoor thermal comfort significantly affects the health 
and productivity of the occupants of a building [15]. Overall, the passive cooling technique is considered to be a sustainable technique to meet current thermal demands due to its use of renewable sources of energy [16]. Therefore, relying only on cooling systems powered by conventional energy has resulted in an increase in the demand for fossil fuel-based energy in the future, hindering the global establishment of thermal energy storage based on renewable energy. Various recently developed impeccable renewable energy passive cooling technologies to make building envelopes sustainable have been innovated and broadly classified into heat protection, heat modulation and heat dissipation techniques [17]. The detailed classification of active and passive cooling techniques is presented in Figure 2.

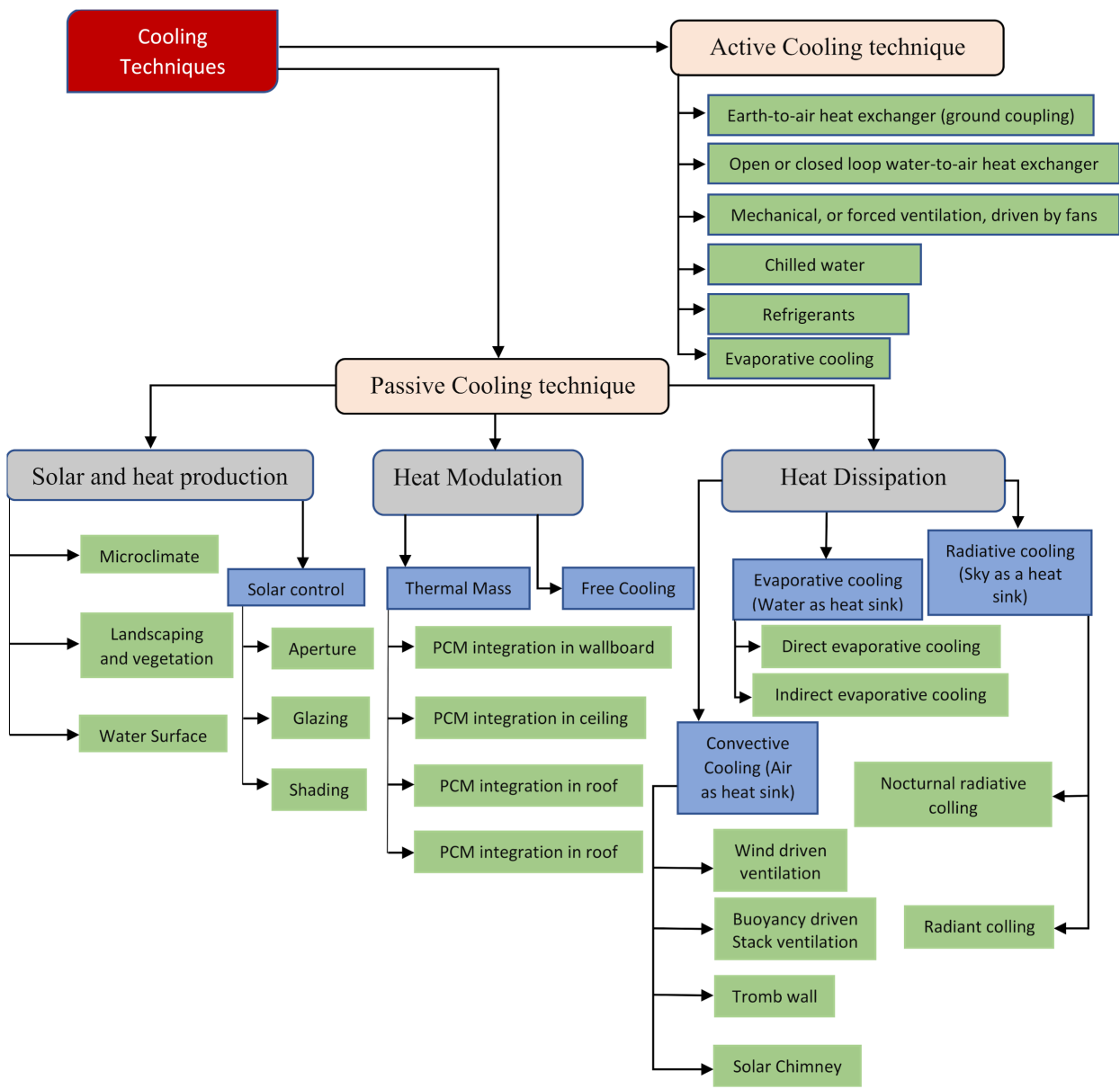

Figure 2. Various active and passive cooling techniques [16,17].

Over the last decade, thermal energy storage (TES) has been a promising technology to achieve a low-carbon future [18]. In fact, the application of phase-change materials (PCM) to enhance the TES for thermal comfort is widely accepted [19]. PCM is recognized as a potential game changer in the field of sustainable infrastructure development and is also feasible for built environment sustainability [20]. Therefore, the use of PCM in the building can be a tradeoff between the future energy demand and the goal of reducing fossil fuel consumption to promote infrastructure related to the UN SDGs.

The successful application of PCM in building to attain thermal comfort has been reported [21-24]. A simulation of PCM building bricks reported by the Alawadhi [25] revealed that the PCM placement at the centerline location of PCM cylinders is best in terms of thermal effectiveness while also helping to maintain the strength of the bricks. A study conducted by Zhuang et al. [26] reported that PCM placed close to the inner side of a hollow block outperformed in terms of thermal performance. However, the use of PCM with different placements in concrete blocks enhances the thermal performance to a different extent depending on its use. In addition, the interaction between PCM and 
cementitious materials is an issue of concern. Accordingly, different techniques of PCM inclusion in building materials, such as alveolar bricks, hollow bricks and CSM panels, have been tested [27]. Therefore, different non-contact incorporation methods of PCM with concrete are attracting much attention among sustainable building researchers [28,29]. Eventually, PCM incorporation in construction materials will support the UN SDGs, but no attempts have been made to correlate the contributions of PCM concrete composites to realize the UN SDGs.

Therefore, the present study is an attempt to connect the contributions of PCM composite concrete as a building material with the UN SDGs. The use of PCM undoubtedly affects the architectural planning, material selection, execution, repair and rehabilitation, and demolition waste-management stages associated with building lifetimes. Efforts are made to address the impact of the use of PCM on the different stages of building lifetimes in this study as well.

\section{Phase Change Materials}

Before defining PCM holistically, a brief explanation of alternative energy storage methods would be beneficial. Ultimately, energy storage is a top priority for reducing fossil fuel consumption, but a sustainable method of energy storage must be practical and long-lasting. Figure 3 shows the different method for the storage of energy. Energy storage methods are categorized into four different types: mechanical energy storage, electrical energy storage, thermochemical energy storage, and thermal energy storage. The thermal energy storage type is a practical method in line with the United Nations SDGs following the consumption of clean energy for thermal comfort in the building sector. Thermal energy can be stored via a change in the internal energy of a material as sensible heat, latent heat, and thermochemical heat, or a combination of these [30-32]. The thermochemical energy storage method demonstrates the highest heat storage density compared to the latent heat and sensible heat storage methods, as shown in Figure 4. However, poor performance in terms of the heat and mass transfer of the thermochemical energy storage method is reported when experimental tests are run [33].

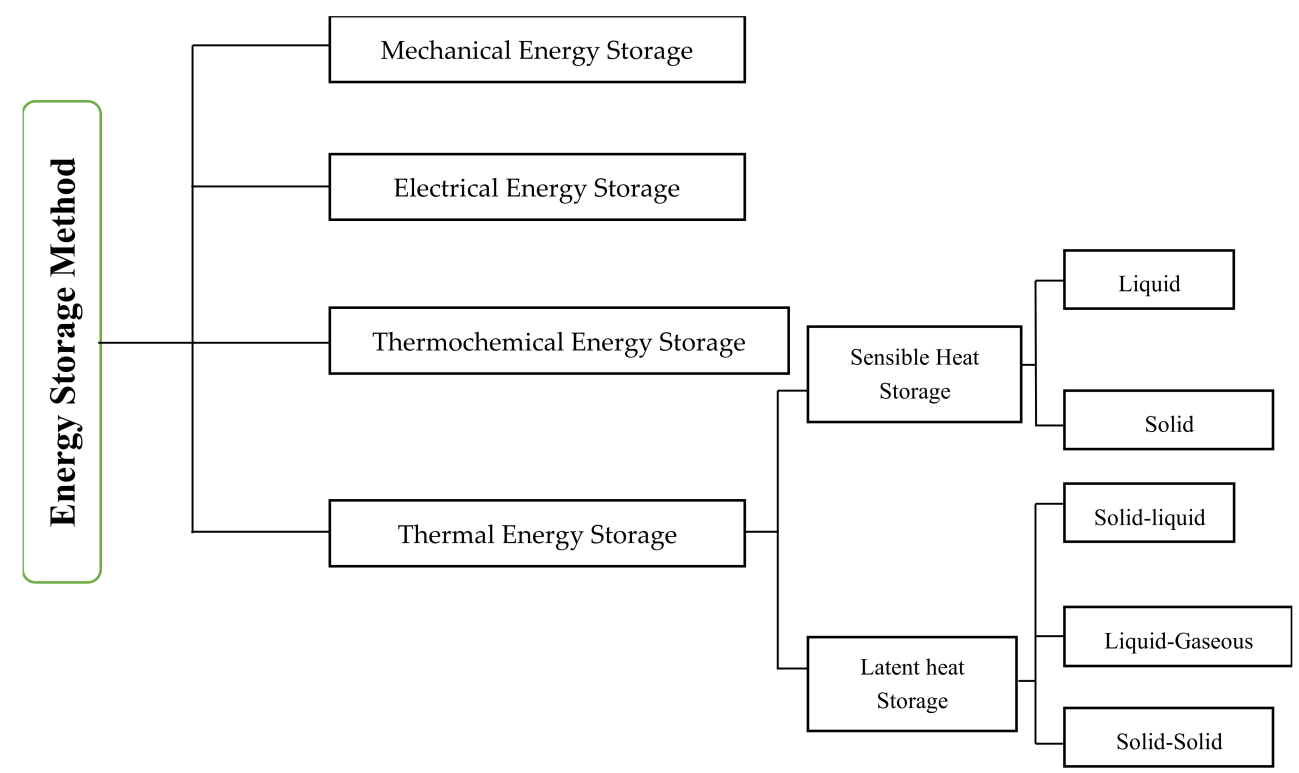

Figure 3. Different type of energy storage method [31,32]. 


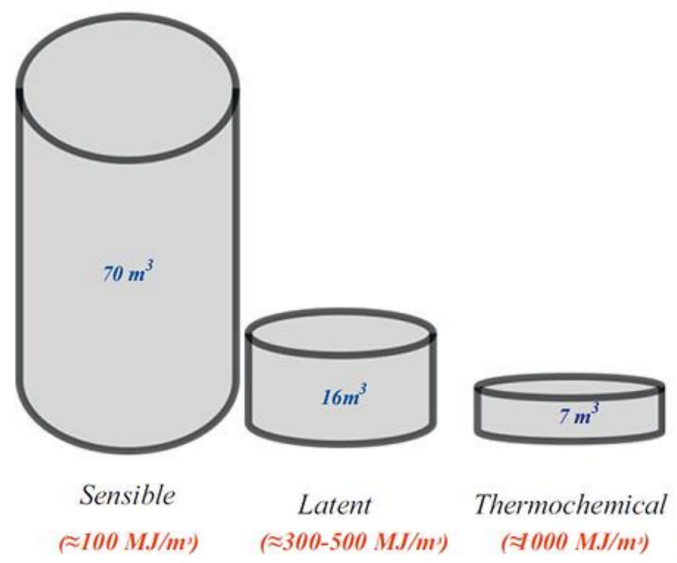

Figure 4. Volume needed to full cover the annual storage needs of an energy efficient passive house (6480 MJ) [33].

Furthermore, a comparison between latent heat storage (LHS) and sensible heat storage (SHS) shows that the thermal energy storage density of latent heat storage is higher than that of sensible heat storage [34,35]. Additionally, the temperature range of LHS required to store and release heat is narrower than that of SHS [36-38]. A large amount of latent heat is absorbed/released by the PCM during the process of transforming the physical properties, i.e., from a solid to a liquid or a liquid to a solid [39-41]. Unlike conventional (sensible) storage materials, PCM absorbs and releases heat at a nearly constant temperature, as shown in Figure 5.

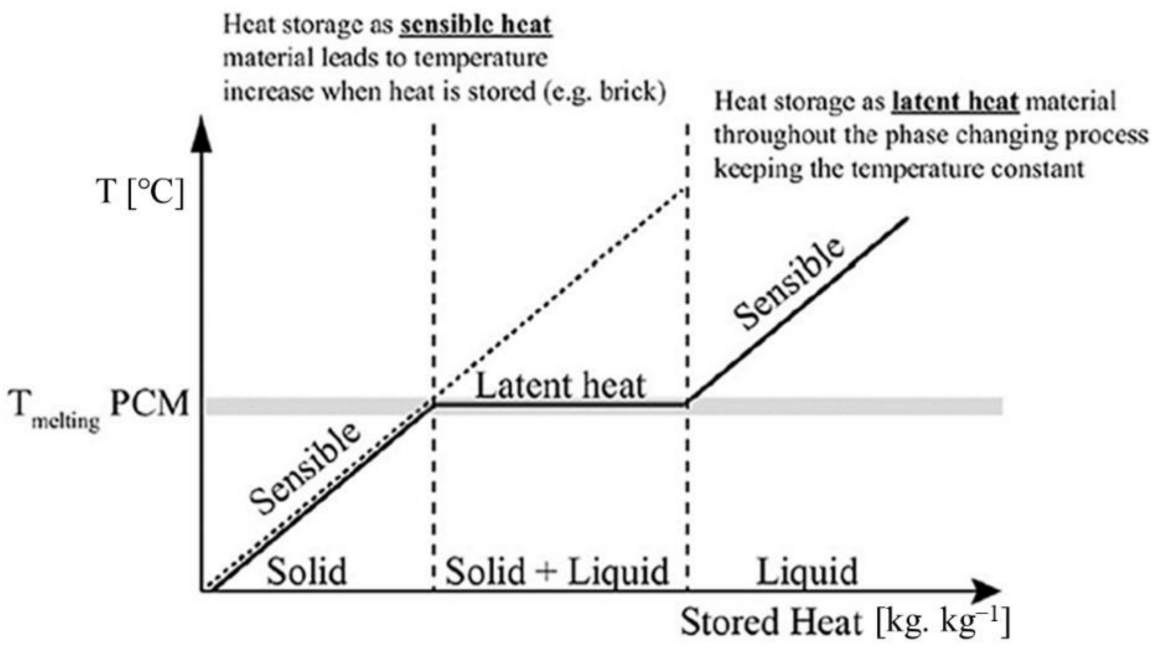

Figure 5. Latent heat storage for the case solid-liquid [41].

PCM can store five to fourteen times more heat per unit volume than sensible storage materials (water, masonry, or rock) [42-44]. Kuznik et al. [42] conducted a simulation using their in-house software CODYMUR to optimize the wallboard. The outcome of the experimental study sought to achieve the optimum thickness of PCM. A thickness of $10 \mathrm{~mm}$ of PCM was reported to be an optimal thickness. Furthermore, energy storage capabilities of $10 \mathrm{~mm}$-thick PCM were compared with those of other materials, as shown in Figure 6. It was observed that latent-heat-based PCM shows enhanced storable energy capabilities, improving the thermal energy storage capacity. Therefore, LHS-based PCM is reported as the most practically relevant thermal storage material for building applications. 


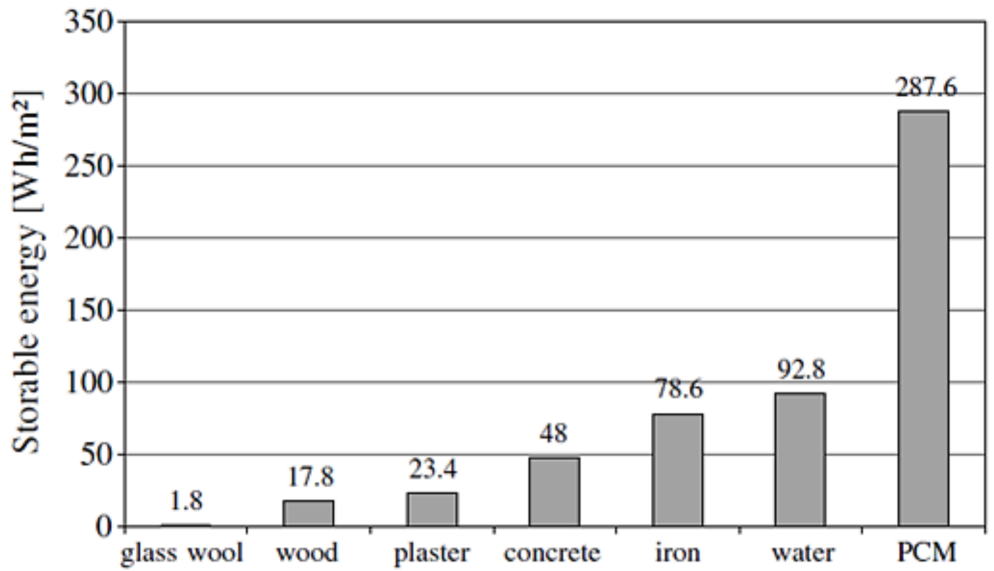

Figure 6. Maximum storable energy between $18^{\circ} \mathrm{C}$ and $26^{\circ} \mathrm{C}$ for $10 \mathrm{~mm}$ of material and for $24 \mathrm{~h} \mathrm{[42].}$

Figure 7 shows the various types of PCMs. Among these PCMs, organic, inorganic and eutectic types are used broadly in buildings [45,46]. Specifically, the selection of a PCM depends upon its temperature range. A temperature range of $20-32{ }^{\circ} \mathrm{C}$ is the accepted range for passive heating and cooling of a building with PCMs [21,47]. A detailed discussion of PCMs is provided in the subsections below.

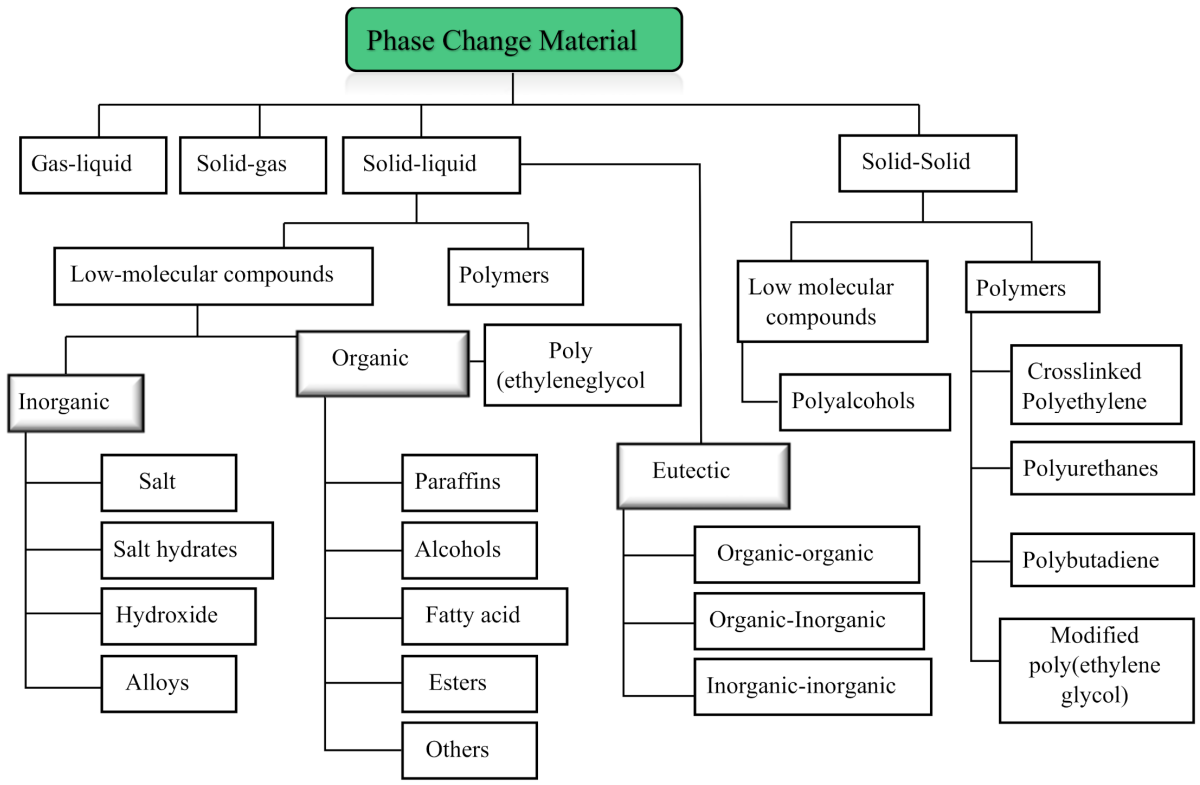

Figure 7. Classification of phase change materials [45-47].

\subsection{Organic PCMs}

Organic PCMs can be either paraffin or non-paraffin type [48]. Paraffin is usually a mixture of straight-chain n-alkanes with the general formula $\mathrm{CH}_{3}-\left(\mathrm{CH}_{2}\right)_{\mathrm{n}}-\mathrm{CH}_{3}$ [47]. Paraffins are excellent energy storage and passive cooling PCMs due to several inherent properties: high latent fusion heating, a wide temperature range of transitional availability, a low cost, and desirable physical and chemical properties, such as congruent fusion with little or no therapeutic hysteresis [31,49]. Organic PCMs are more chemically stable and melt congruently, meaning that super-cooling is not a significant problem [50]. However, organic PCM exhibits low thermal conductivity, making the rate of heat storage/release of organic PCM low [51-54]. Acid $\left(\mathrm{CH}_{3}\left(\mathrm{CH}_{2}\right)_{2 \mathrm{n}} \mathrm{COOH}\right)$ is the primary organic non-paraffin PCM [55]. Its melting point is comparable to that of the paraffin PCM, and it has excellent melting and freezing characteristics. However, the cost of non-paraffin PCMs is nearly three times that of paraffin PCMs [50]. Fatty acids and their acid esters and alcohols, glycols, etc., 
are non-paraffin types used as PCMs, and among these, fatty acids are the most commonly used PCMs in building applications for thermal storage [56]. The latent heat and melting properties of the various PCMs used in buildings are shown in Table 1.

\subsection{Inorganic PCMs}

Inorganic PCMs are salt hydrates $\left(\mathrm{MnH}_{2} \mathrm{O}\right)$, nitrates, and metallic materials having a slightly high heat of fusion. Some of their properties, such as high volumetric latent heat storage capacities, non-flammability, and high thermal conductivity make these materials appropriate for building applications. Furthermore, they are inexpensive and readily available [57]. However, some of the disadvantages are corrosion to most metals, phase separation and segregation, a lack of thermal stability, and supercooling during the solid-liquid transition process $[50,58]$. Super-cooling is defined as a "delay in the start of solidification," taking place whenever a PCM undergoes a phase change from a liquid to a solid [59]. As a result, for full utilization of the latent heat, a large temperature difference between charging and discharging is required, which is undesirable for efficient energy storage applications [60]. Specifically, a realistic possibility for minimizing supercooling is to introduce sufficiently large PCM microcapsules, but the interaction with the large diameter of the PCM often breaks down during the mixing process when using these materials in building applications [61,62]. Another concern with inorganic PCMs is their degradation and breakdown after repeated phase-change cycles. Among all inorganic PCMs, salt hydrates are widely studied for thermal energy storage.

\subsection{Eutectic PCMs}

Eutectics are organic and/or inorganic compound mixtures [63-65]. As a result, eutectics can be created as organic-organic, inorganic-inorganic, or organic-inorganic mixtures [66]. Eutectic PCMs have a higher density than organics and a single melting temperature and therefore do not separate into components during a phase change [67]. As a result, phase separation and super-cooling are not observed in these materials. Eutectics usually have a high thermal cycle, particularly in comparison to salt hydrates (inorganic PCM). The eutectic PCM offers the flexibility of customizing the melting temperature and enthalpy according to the actual field application. Therefore, eutectic PCMs with lower melting peak temperatures have received substantial attention in the building sector [65]. Mert et al. [68] encapsulated a mixture of capric acid and oleic acid containing hexadecane in styrene-divinylbenzene copolymer shells via an emulsion polymerization technique. The obtained melting point range and enthalpy were $14.1-24{ }^{\circ} \mathrm{C}$ and $123 \mathrm{~J} / \mathrm{g}$, indicating suitability for thermal storage in building applications. Further, recent research is focused on thermal conductive enhancements of eutectic PCMs using thermal conductive fillers (carbon-based materials and nanoparticles) [69,70]. Some of these eutectic mixtures with their melting points and latent heat values are depicted in Table 1. 
Table 1. Melting point and latent heat of different types of (a) organic [31,71-74], (b) inorganic [75-77], and (c) eutectic [64,65,78-81] type of PCM.

\begin{tabular}{|c|c|c|c|c|c|c|c|c|}
\hline \multicolumn{3}{|c|}{ Organic PCM } & \multicolumn{3}{|c|}{ Inorganic PCM } & \multicolumn{3}{|c|}{ Eutectic PCM } \\
\hline PCM Type & $\begin{array}{l}\text { Melting Point } \\
\left({ }^{\circ} \mathrm{C}\right)\end{array}$ & $\begin{array}{l}\text { Latent Heat of } \\
\text { Fusion }(\mathrm{kJ} / \mathrm{kg})\end{array}$ & PCM Type & $\begin{array}{l}\text { Melting Point } \\
\left({ }^{\circ} \mathrm{C}\right)\end{array}$ & $\begin{array}{l}\text { Latent Heat of } \\
\text { Fusion }(k J / k g)\end{array}$ & PCM Type & $\begin{array}{c}\text { Melting Point } \\
\left({ }^{\circ} \mathrm{C}\right)\end{array}$ & $\begin{array}{l}\text { Latent Heat of } \\
\text { Fusion }(\mathrm{kJ} / \mathrm{kg})\end{array}$ \\
\hline Paraffin C17 & 21.7 & 213 & $\mathrm{~K}_{2} \mathrm{HPO}_{4} \cdot 6 \mathrm{H}_{2} \mathrm{O}$ & 14 & 109 & $\begin{array}{l}\text { Capric Acid/Palmitic } \\
\text { Acid/Stearic Acid }\end{array}$ & 19.83 & 154.11 \\
\hline Paraffin C 18 & 28 & 244 & $\mathrm{LiNO}_{3} \cdot 2 \mathrm{H}_{2} \mathrm{O}$ & 30 & 296 & $\begin{array}{l}\text { Hexadecanol/Palmitic } \\
\text { Acid/Lauric Acid }\end{array}$ & 26.527 & 179.63 \\
\hline Butyl stearate & 19 & 140 & $\mathrm{LiNO}_{3} \cdot 3 \mathrm{H}_{2} \mathrm{O}$ & 30 & 189 & Lauric/Palmitic/Steric Acid & 36.79 & 159 \\
\hline Emerest 2326 & 20 & 139 & $\mathrm{CaCl}_{2} \cdot 12 \mathrm{H}_{2} \mathrm{O}$ & 29.8 & 174 & $\begin{array}{l}\text { Capric Acid/Myristic } \\
\text { Acid/Palmitic Acid }\end{array}$ & 17 & 131.7 \\
\hline $\begin{array}{l}\text { Tetradecane } \\
\left(\mathrm{C}_{14} \mathrm{H}_{20}\right)\end{array}$ & 5 & 172.21 & $\mathrm{CaBr}_{2} \cdot 6 \mathrm{H}_{2} \mathrm{O}$ & 34 & 138 & $\begin{array}{c}\text { Oleic acid/Isopropyl } \\
\text { Palmitate/Butyl stearate }\end{array}$ & 5.14 & 104.12 \\
\hline $\begin{array}{l}\text { Paraffin waxes } \\
\text { RT45 }\end{array}$ & 45 & 160 & $\mathrm{LiClO}_{3} \cdot 3 \mathrm{H}_{2} \mathrm{O}$ & 8 & 253 & $\begin{array}{c}53 \% \mathrm{Mg}\left(\mathrm{NO}_{3}\right)_{2} \cdot 6 \mathrm{H}_{2} \mathrm{O}+47 \% \\
\mathrm{AL}\left(\mathrm{NO}_{3}\right)_{2} \cdot 9 \mathrm{H}_{2} \mathrm{O}\end{array}$ & 66 & 168 \\
\hline Formic acid & 7.8 & 247 & $\mathrm{Na}_{2} \mathrm{SO}_{4} \cdot 10 \mathrm{H}_{2} \mathrm{O}$ & 32.4 & 248 & $\begin{array}{c}55 \% \mathrm{CaCl}_{2} \cdot 6 \mathrm{H}_{2} \mathrm{O}+45 \% \\
\qquad \mathrm{CaBr}_{2} \cdot 6 \mathrm{H}_{2} \mathrm{O}\end{array}$ & 14.7 & 140 \\
\hline Glycerin & 17.9 & 198.7 & $\mathrm{Na}_{2} \mathrm{CO}_{3} \cdot 10 \mathrm{H}_{2} \mathrm{O}$ & 33 & 247 & - & - & - \\
\hline
\end{tabular}




\section{PCM Incorporation in Concrete}

Figure 8 shows the four different methods of PCM incorporation in concrete. These four methods of PCM incorporation in concrete and their performance capabilities in terms of their thermal, mechanical, and durability properties are outlined in this section. The selection of the PCM type and the associated method of incorporation in concrete significantly influence the overall performance of the concrete. Therefore, this section is prepared to assist designers and executive engineers to enrich their decisions while selecting PCMs for thermal storage applications in concrete.

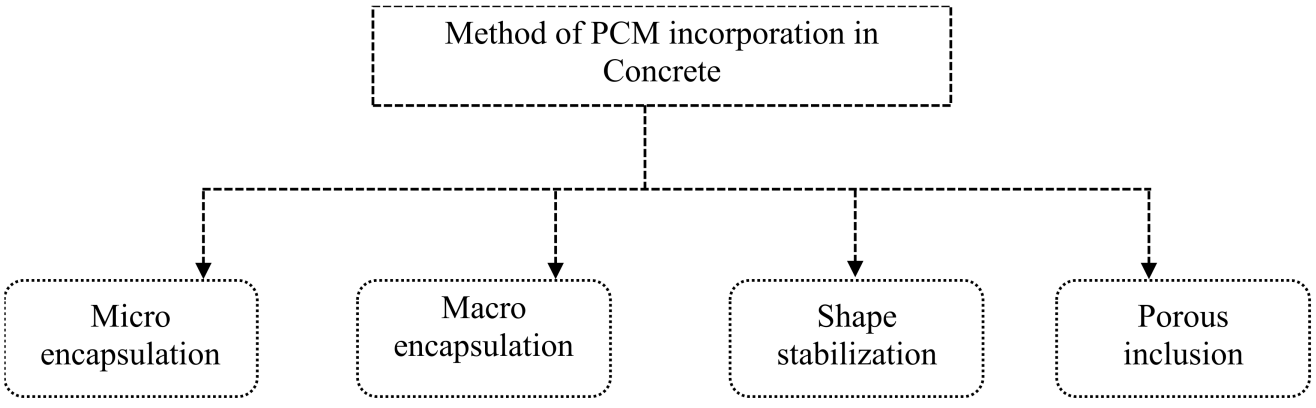

Figure 8. Four different methods of incorporating PCM in concrete.

Microencapsulation is a method of placing the PCM in a polymeric shell. The hollow capsules made of a polymeric shell filled with PCM were manufactured between 1 and $300 \mu \mathrm{m}$ sizes [82]. The outer shell acts as a container for the PCM. Therefore, PCM can store as a core material in liquid or solid form in the polymer shell. The PCM having a phase change temperature between $-10{ }^{\circ} \mathrm{C}$ to $80^{\circ} \mathrm{C}$ is suitable for manufacturing the microcapsules [83]. The microencapsulated PCM (MPCM) was used successfully in the walls, roof, floors, gypsum wallboards, plaster, and mortar [84]. However, the demerits associated with MPCM are the low stiffness and strength compared to the ingredients of cement-based building materials. In addition, the leakage of MPCM in concrete during mixing degrades the mechanical properties of concrete [85]. The reduction in strength was due to the direct interaction of PCM with the cement matrix [86]. Macro encapsulation technique is similar to microencapsulation, but the size of the container for preserving the PCM is large such as a tube, spheres, or panels. The size of these containers is generally greater than $1 \mathrm{~cm}$ [81]. The component prepared using this technology can directly serve as a building element. However, some of the issues like leakage, poor heat transfer characteristics, and solidification at edges are the demerits of the macro encapsulation technique [87]. The third technique is shape stabilization focused on PCM preparation using supporting material. High-density polyethylene and styrene-butadiene-styrene are the common supporting material for manufacturing the shape-stabilized PCM. The mixture of PCM and supporting material melted and then mixed properly at high temperature. The PCM and supporting material mixture allow to cool down below the glass transition temperature of the supporting materials until it becomes solid. The advantage of this PCM is large apparent specific heat for phase change temperature region, stabilized shape during the phase change process, and no requirement of container [88]. This processing prevents the PCM leakage, but the lower thermal conductivity of the shape stabilized PCM limits its wide adaptability [89]. The porous inclusion technique follows the impregnation of PCM into the porous inclusions, and that composite material can be used in concrete for improving the thermal insulation [90]. Among these techniques, the research on PCMfilled lightweight aggregate and its effect on mechanical and thermal performance has been widely conducted [91,92]. Hitherto, concrete was specifically designed to obtain robust mechanical properties and durability. However, the concept of tailored concrete accelerated the production of a variety of concrete in the infrastructure industries. PCMintegrated concrete is also a type of tailored concrete, precisely developed to enhance the 
thermal properties (e.g., thermal conductivity, specific heat capacity, thermal diffusivity). However, the use of PCM in concrete via micro encapsulation, macro encapsulation, shape stabilization and porous inclusion technique decreases the strength and density of the concrete and increase the porosity [93]. Specifically, the leakage of PCMs in the liquid state [86,94-97], and interference of PCMs with cement hydration is the cause of strength reduction [98-100]. Therefore, the present study gathered information and presented an overview from the published literature with regard to PCM incorporation methods, procedures of incorporation into the matrix, the percentage of PCM use in the matrix, and effect of incorporation of PCM on the different properties of mortar/concrete, as summarized in Table 2. Accordingly, this field remains open for further investigations to realize safe, durable and PCM-compatible concrete.

Improvements in the thermal performance of concrete have been achieved using PCMs in concrete irrespective of the method adopted among the four described in Figure 8. The major impact of using PCM in concrete was observed on the mechanical performance of concrete, as presented in Table 2. The decrease in the overall mechanical properties of concrete is due to the chemical reaction and physical interaction with concrete materials [101-103]. The interactions of PCM and cement hydration products result in a decrease in the calcium silica hydrate crystallization in the cement matrix and produce a weaker phase in the cement binding system [36,86]. Therefore, the safe deposition of PCM into a lightweight aggregate along the coating of supplementary cementitious materials onto the outer surface can have the least negative effect on the concrete mechanical properties [29,104].

One fact that cannot be ignored is that the feasibility of PCM-incorporated concrete on a large scale in a field application is only possible when PCM has a neutral effect or minimal effect on the mechanical properties of concrete. The mass application of PCM-incorporated concrete can significantly decrease the fossil-fuel-based energy demand and contribute to the realization of the UN SDGs. Therefore, in the upcoming section, the possible benefits of using PCM in infrastructure, the mapping between PCM concrete composites and UN SDGs, and expected alterations in the traditional infrastructure practices are addressed. 
Table 2. Different method of incorporating the PCM in concrete/mortar and their performance outcome.

\begin{tabular}{|c|c|c|c|c|c|}
\hline Ref. & $\begin{array}{l}\text { Material Type/Method of } \\
\text { PCM Incorporation }\end{array}$ & PCM Name & Replacement/Addition & Properties Investigated & $\begin{array}{c}\text { Performance } \\
\text { (Improvement/Decrement) }\end{array}$ \\
\hline \multirow[t]{4}{*}{ [93] } & \multirow[t]{4}{*}{ Mortar/Micro encapsulation } & \multirow[t]{4}{*}{$\begin{array}{c}\text { Paraffin based } \\
\text { microencapsulated PCM } \\
\text { (Micronal DS 5040X) }\end{array}$} & \multirow[t]{4}{*}{$\begin{array}{l}\text { Sand replaced with } 1 \%, 3 \% \\
\text { and } 5 \% \text { PCM by mass }\end{array}$} & Isothermal calorimetry & $\begin{array}{l}\text { Increment and delay in maximum rate of heat of } \\
\text { hydration compared with the control mix. }\end{array}$ \\
\hline & & & & Thermogravimetry & $\begin{array}{l}\text { Dehydration of C-S-H and dehydroxylation of } \mathrm{CH} \\
\text { were observed in the range of } 35^{\circ} \mathrm{C} \text { to } 540^{\circ} \mathrm{C} \text {. }\end{array}$ \\
\hline & & & & $\begin{array}{l}\text { Differential scanning } \\
\text { calorimetry }\end{array}$ & $\begin{array}{l}\text { Higher weight loss was observed throughout the } \\
\text { temperature range of } 50{ }^{\circ} \mathrm{C} \text { to } 800^{\circ} \mathrm{C}\end{array}$ \\
\hline & & & & Compressive Strength & $\begin{array}{l}\text { Soft microencapsulated PCM increases the porosity, } \\
\text { so strength decreases. }\end{array}$ \\
\hline \multirow[t]{3}{*}{ [105] } & \multirow[t]{3}{*}{$\begin{array}{c}\text { High Performance hybrid } \\
\text { fiber engineered cementitious } \\
\text { compos- } \\
\text { ites/Microencapsulation }\end{array}$} & \multirow[t]{3}{*}{$\begin{array}{l}\text { Micro PCM (Maximum } \\
\text { particle size up to } 300 \mu \mathrm{m})\end{array}$} & \multirow[t]{3}{*}{$\begin{array}{l}\text { Silica sand replaced with } \\
\text { micro PCM by } 1 \%, 2 \%, 3 \% \\
\text { and } 5 \% \text { by weight }\end{array}$} & Compressive strength & $\begin{array}{l}16.39 \% \text { reduction at } 28 \text { days of ECC having } 5 \% \\
\text { PCM. }\end{array}$ \\
\hline & & & & Thermal conductivity & $\begin{array}{l}\text { Increase in the amount of micro PCM displays very } \\
\text { little change between } 0.90 \text { and } 1.1 \mathrm{~W} / \mathrm{mK}\end{array}$ \\
\hline & & & & Specific heat value & $\begin{array}{l}\text { Increases the phase change enthalpy in the interval } \\
\left(56-72^{\circ} \mathrm{C}\right) \text { which, in turn, results in a thermal } \\
\text { absorption capacity increase. }\end{array}$ \\
\hline \multirow[t]{4}{*}{ [106] } & \multirow[t]{4}{*}{$\begin{array}{l}\text { Ultra-high-performance } \\
\text { concrete } \\
\text { (UHPC)/Microencapsulation }\end{array}$} & \multirow[t]{4}{*}{$\begin{array}{l}\text { Paraffin wax based micro } \\
\text { encapsulated PCM (MPCM) }\end{array}$} & \multirow[t]{4}{*}{$\begin{array}{l}5 \% \text { and } 10 \% \text { MPCM by } \\
\text { weight of binder added in the } \\
\text { mix }\end{array}$} & Compressive strength & $\begin{array}{l}\text { Compressive strength of UHPC decreases because } \\
\text { of the low strength of microcapsules and leakage in } \\
\text { mortar while mixing. }\end{array}$ \\
\hline & & & & Thermal conductivity & Decreases with the increase of MPCM content. \\
\hline & & & & Heat storage capacity & $\begin{array}{l}\text { Increase in the heat storage capacity determined by } \\
\text { differential scanning calorimetry. }\end{array}$ \\
\hline & & & & $\begin{array}{l}\text { Mercury intrusion } \\
\text { porosimetry (MIP) }\end{array}$ & $\begin{array}{l}\text { Capillary and transition pore volume increases } \\
\text { sharply with the incorporation of MPCM, but the } \\
\text { proportion of gel and large pores is relatively small. }\end{array}$ \\
\hline
\end{tabular}


Table 2. Cont.

\begin{tabular}{|c|c|c|c|c|c|}
\hline Ref. & $\begin{array}{l}\text { Material Type/Method of } \\
\text { PCM Incorporation }\end{array}$ & PCM Name & Replacement/Addition & Properties Investigated & $\begin{array}{c}\text { Performance } \\
\text { (Improvement/Decrement) }\end{array}$ \\
\hline \multirow[t]{3}{*}{ [86] } & $\begin{array}{l}\text { Self-compacted } \\
\text { concrete/Micro- } \\
\text { encapsulation }\end{array}$ & $\begin{array}{l}\text { Mixture of paraffin waxes in } \\
\text { powder form, encapsulated } \\
\text { in polymethyl methacrylate } \\
\text { microcapsules, Micronal (DS } \\
5008 \text { X) }\end{array}$ & $\begin{array}{l}1 \%, 3 \% \text { and } 5 \% \text { by mass of } \\
\text { concrete added in the } \\
\text { self-compacted concrete. }\end{array}$ & Compressive strength & $\begin{array}{l}\text { Increasing PCM dosages lead to significantly lower } \\
\text { the compressive strengths. }\end{array}$ \\
\hline & & & & Thermal conductivity & $\begin{array}{l}\text { The addition of PCM particles into the mass of the } \\
\text { concrete results in a reduction of thermal } \\
\text { conductivity. }\end{array}$ \\
\hline & & & & Specific heat capacity & $\begin{array}{l}\text { Increasing the amount of PCM in the mixture } \\
\text { increases significantly its specific heat capacity (up } \\
\text { to } 3.5 \text { times for the } 5 \% \text { PCM content). }\end{array}$ \\
\hline [82] & Mortar/Microencapsulation & $\begin{array}{l}\text { n-octadecane }\left(\mathrm{C}_{18} \mathrm{H}_{38}\right) \\
\text { impregnated in the } \\
\text { ceno-spheres }\end{array}$ & $\begin{array}{l}\text { Mortar (reference mix) } \\
\text { without CenoPCM Mortar } \\
\text { without sealed CenoPCM. } \\
\text { Mortar with sealed CenoPCM }\end{array}$ & Compressive strength & $\begin{array}{c}\text { Mortar without CenoPCM (Reference mix) attained } \\
50.80 \mathrm{MPa} \text { strength at } 28 \text { days of curing. Mortar } \\
\text { without sealed CenoPCM attained } 42.87 \mathrm{MPa} \\
\text { strength at } 28 \text { days curing. Mortar with sealed } \\
\text { (silica sol) CenoPCM exhibited } 47.96 \mathrm{MPa} \text { strength } \\
\text { at } 28 \text { days of curing. The lowest strength in the } \\
\text { mortar containing unsealed CenoPCM could be } \\
\text { partially attributed to the PCM absorbed on the } \\
\text { shell surface. }\end{array}$ \\
\hline \multirow[t]{2}{*}{ [107] } & $\begin{array}{l}\text { Structural-functional } \\
\text { integrated Con- } \\
\text { crete/Macroencapsulation }\end{array}$ & $\begin{array}{l}\text { Commercial inorganic PCM } \\
\text { (Rubitherm SP22) } \\
\text { impregnated in lightweight } \\
\text { aggregate (LWA) }\end{array}$ & $\begin{array}{l}\text { PCM-lightweight aggregate } \\
\text { (LWA) as partial replacement } \\
\text { (25 and } 50 \% \text { by volume) of } \\
\text { coarse aggregate }\end{array}$ & Compressive strength & $\begin{array}{l}\text { Increasing PCM-LWA in a mix cause in a reduction } \\
\text { in strength. }\end{array}$ \\
\hline & & & & $\begin{array}{l}\text { Thermal performance of } \\
\text { PCM-LWA panel }\end{array}$ & $\begin{array}{l}\text { PCM-LWA has the ability to reduce the energy } \\
\text { consumption by reducing the indoor temperature } \\
\text { and shifting the loads away from the peak periods. }\end{array}$ \\
\hline \multirow[t]{2}{*}{ [108] } & $\begin{array}{l}\text { Structural-functional } \\
\text { integrated Concrete/ } \\
\text { Macro-encapsulation }\end{array}$ & $\begin{array}{l}\text { Macro-encapsulated paraffin } \\
\text { lightweight aggregate (LWA). }\end{array}$ & $\begin{array}{l}7 \%, 33 \% \text { and } 50 \% \\
\text { macro-encapsulated } \\
\text { paraffin-LWA by volume of } \\
\text { normal weight aggregate }\end{array}$ & Compressive strength & $\begin{array}{l}\text { Compressive strength of macro encapsulated } \\
\text { paraffin lightweight aggregate contained concrete is } \\
\text { higher than the only LWA contained concrete. }\end{array}$ \\
\hline & & & & Thermal Performance & $\begin{array}{c}\text { Rooms with macro-encapsulated paraffin-LWA } \\
\text { show a lower indoor temperature as compared to } \\
\text { the control room model during the heating and } \\
\text { cooling process. }\end{array}$ \\
\hline
\end{tabular}


Table 2. Cont.

\begin{tabular}{|c|c|c|c|c|c|}
\hline Ref. & $\begin{array}{l}\text { Material Type/Method of } \\
\text { PCM Incorporation }\end{array}$ & PCM Name & Replacement/Addition & Properties Investigated & $\begin{array}{c}\text { Performance } \\
\text { (Improvement/Decrement) }\end{array}$ \\
\hline \multirow[t]{2}{*}{ [109] } & Concrete/Macroencapsulation & Paraffin octadecane (PO) & $\begin{array}{l}\text { Replacing } 25 \%, 50 \%, 75 \% \text { and } \\
100 \% \text { of gravel normal coarse } \\
\text { aggregate with PO filled } \\
\text { hollow steel balls }\end{array}$ & Compressive strength & $\begin{array}{l}\text { PCM contained concrete strength decreased with } \\
\text { the increases in PCM content in the mix. }\end{array}$ \\
\hline & & & & $\begin{array}{l}\text { Thermal performance of } \\
\text { macro encapsulated } \\
\text { PCM-HSB incorporated } \\
\text { concrete panel }\end{array}$ & $\begin{array}{l}\text { PCM contained concrete panel efficiently reducing } \\
\text { the peak indoor air temperature in the range of } \\
25-33 \% \text { compared to control specimen. }\end{array}$ \\
\hline [110] & $\begin{array}{l}\text { Macro PCM contained hollow } \\
\text { fire clay brick wall/Macro } \\
\text { encapsulation }\end{array}$ & $\begin{array}{l}\text { Metal steel macro-capsules } \\
\text { filled with organic paraffin }\end{array}$ & - & Thermal performance & $\begin{array}{l}\text { High thermal amplitude reduction of the wall } \\
\text { specimens with PCM compared with the wall } \\
\text { without PCM. }\end{array}$ \\
\hline$[90]$ & $\begin{array}{l}\text { Light weight aggregate } \\
\text { (LWA) used as PCM host. }\end{array}$ & paraffin-based liquid PCM & 5\% PCM by overall volume & $\begin{array}{l}\text { Thermal conductivity } \\
\text { Compressive strength }\end{array}$ & $\begin{array}{l}\text { PCM impregnated LWA mortars show thermal } \\
\text { conductivities } 10 \% \text { to } 20 \% \text { lower than the regular } \\
\text { LWA (water-saturated) mortars, at a total PCM } \\
\text { content of } 5 \% \text { by volume in the mortars. } \\
\text { The PCM contained LWA perform equivalent to } \\
\text { water contained LWA due to the no leakage of PCM } \\
\text { from the LWA during heat storage and released. }\end{array}$ \\
\hline [111] & $\begin{array}{l}\text { PCM impregnated light } \\
\text { weight aggregate } \\
\text { (LWA)/Porous inclusion }\end{array}$ & - & - & $\begin{array}{l}\text { Differential scanning } \\
\text { calorimetry }\end{array}$ & $\begin{array}{l}\text { The EP/erythritol composite prepared by the } \\
\text { vacuum impregnation treatment had the largest } \\
\text { latent heat, which was } 83 \% \text { of that of pure erythritol. } \\
\text { The latent heat storage decreases as the cycles of } \\
\text { heating and cooling increased. } \\
\text { Without cycle-334.4 kJ/kg } \\
\text { First Cycle-295.2 kJ/kg } \\
\text { Second Cycle-238.1 kJ/kg }\end{array}$ \\
\hline
\end{tabular}


Table 2. Cont.

\begin{tabular}{|c|c|c|c|c|c|}
\hline Ref. & $\begin{array}{l}\text { Material Type/Method of } \\
\text { PCM Incorporation }\end{array}$ & PCM Name & Replacement/Addition & Properties Investigated & $\begin{array}{c}\text { Performance } \\
\text { (Improvement/Decrement) }\end{array}$ \\
\hline \multirow[t]{3}{*}{ [112] } & \multirow[t]{3}{*}{$\begin{array}{l}\text { cement mortar/Porous } \\
\text { inclusion }\end{array}$} & \multirow[t]{3}{*}{ Paraffin } & \multirow[t]{3}{*}{$\begin{array}{l}\text { Sand replaced by PCM at the } \\
\text { percentage of } 20,40,60 \text { and } \\
80 \text { by volume. }\end{array}$} & Compressive strength & $\begin{array}{l}28 \text { days strength at replacement levels of } 20 \%, 40 \% \text {, } \\
60 \% \text { and } 80 \% \text { are } 12 \%, 33 \%, 53 \% \text {, and } 70 \% \text { lower } \\
\text { than the control specimen, respectively. }\end{array}$ \\
\hline & & & & Apparent density & $\begin{array}{l}\text { Decreases with the increasing replacement level of } \\
\text { composite PCM. }\end{array}$ \\
\hline & & & & Thermal conductivity & $\begin{array}{l}\text { Decreased with the increasing replacement levels of } \\
\text { composite PCM. }\end{array}$ \\
\hline \multirow[t]{2}{*}{ [113] } & \multirow[t]{2}{*}{$\begin{array}{l}\text { PCM silicon based composite } \\
\text { aggregate/Porous inclusion }\end{array}$} & \multirow[t]{2}{*}{ Paraffin wax } & $\begin{array}{l}\text { PCM/Silicon (SiC) based } \\
\text { composite aggregate } \\
\text { re-placed with } 30 \%, 50 \%, \\
70 \% \text {, and } 100 \% \text { of the natural } \\
\text { coarse aggregate. }\end{array}$ & Thermal conductivity & $\begin{array}{l}\text { Gradually decreased with an increase of the } \\
\text { replacement ratio of the PCM/SiC-based composite } \\
\text { aggregate. }\end{array}$ \\
\hline & & & & Hydration heat development & $\begin{array}{c}\text { Plain sample temperature was significantly } \\
\text { increased compared with samples containing } \\
\text { PCM/SiC-based composite aggregate during } \\
\text { hydration process. }\end{array}$ \\
\hline
\end{tabular}




\section{PCM Contribution to Achieve the UN SDGs}

To align infrastructure development with the low-carbon-emissions target, indefatigable efforts have been put by the United Nations (UN) [114,115]. As a result, SDGs have been established as future goals for developed and developing countries. The UN SDG No. 7 is particularly devoted to affordable and clean energy, and PCMs have a significant role in promoting the use of clean energy [116,117]. The storage and utilization of clean energy with PCMs to achieve thermal comfort in building envelopes meet the different targets of UN SDG 7. Therefore, this section discusses the possible contribution of PCMs to the realization of different targets set under the UN SDGs. First, we emphasize the contribution of PCM to the attainment of the various target of UN SDG 7. Second, we map the use of PCM in concrete considering the UN SDGs. In addition, with the practical implementation of PCM in infrastructure practices, it is slightly challenging to accommodate this material with traditional practices. Therefore, a detailed discussion is presented of the required amendments of traditional construction practices to achieve the safe and quality use of PCMs at various stages of the construction process.

\subsection{PCM Contribution to UN SDG 7}

UN SDG 7 refers to 'affordable and clean energy', with the agenda of providing access to clean energy research and technology, linked to renewable energy, energy efficiency, advanced and cleaner fossil-fuel technologies, investment promotions in energy infrastructure, expansions of infrastructure, and upgrades of technology to supply modern and sustainable energy services for all in developing countries, in particular in the least developed countries. The center of attention of UN SDG 7 is the achievement of clean energy for future development. The attainment of SDG 7 is measured by five targets. Each target is further subdivided into different sections, referred to as 'indicators'. The literature reports that PCMs are among the efficient clean energy materials used in concrete and buildings to improve the thermal comfort of occupants [118]. The growing interest of researchers in PCMs is highly recognized for unfolding the unknown performance parameters of PCM concrete composites as thermal storage building materials [119]. Therefore, the implementation of PCM in a building material directly accelerates the efforts to attain the UN SDG 7. Figure 9 shows the relevance of PCM clean energy storage with the indicators of UN SDG 7.

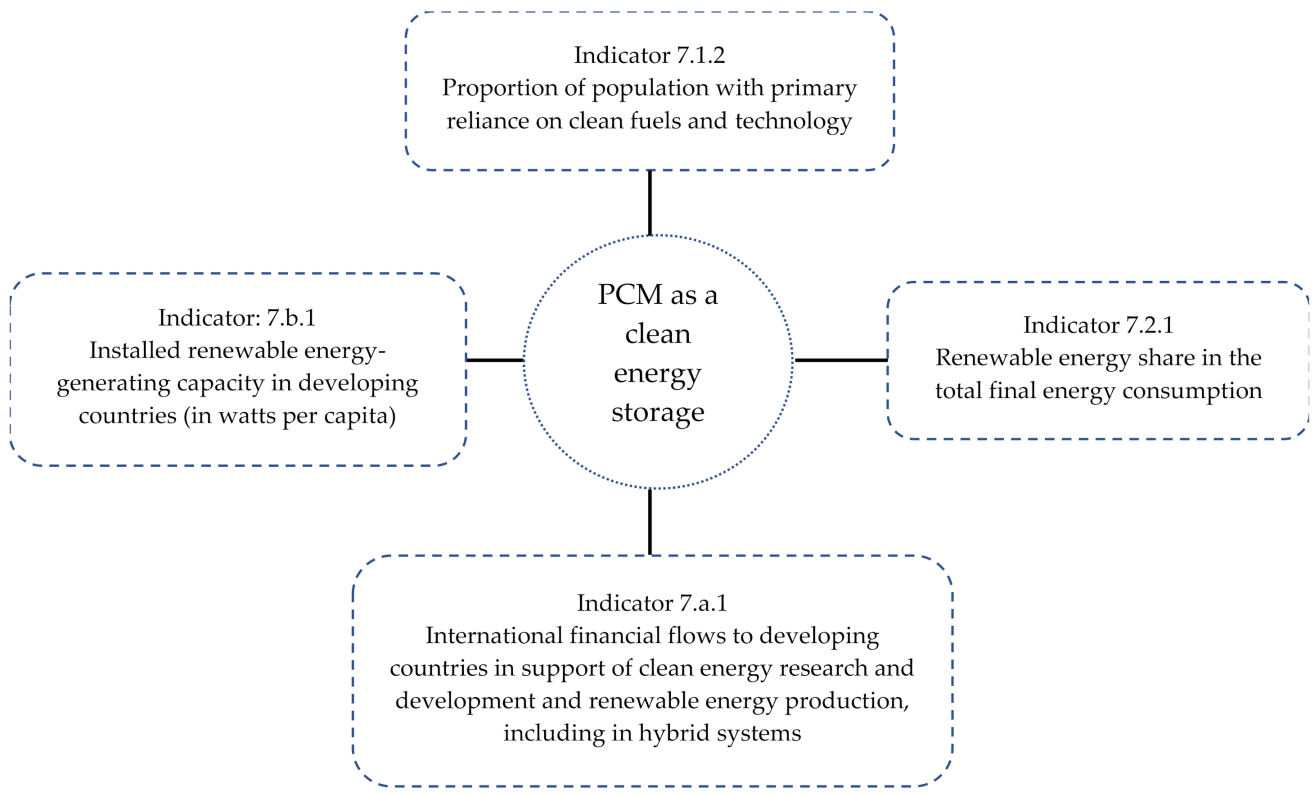

Figure 9. Contribution of PCM in attainment of UN SDGs 7. 
Indicator 7.1.2 guidelines emphasize the use of efficient fuels and technology combinations in all major household energy end uses (e.g., cooking, space heating, lighting) to ensure health benefits. Indicator 7.2.1 shows the energy share out of the total final energy consumption levels. The energy share is specifically denoted as renewable energy in indicator 7.2.1. The renewable energy share out of the total final consumption is the percentage of the final consumption of energy that is derived from renewable resources. Further, the specific renewable energy sources defined in this indicator include the following sources of renewable energy: solar energy including solar PV and solar thermal energy; liquid biofuels including bio-gasoline, biodiesels and other liquid biofuels, solid biofuels including fuelwood, animal waste, vegetable waste, black liquor, bagasse and charcoal; and renewable waste energy covering energy from renewable municipal waste. Up to date, the study describing the direct measurement of UN SDGs attainment by using the PCM in the building materials has not been reported. Nonetheless, the indirect connection between the UN SDGs and PCM can be identified by literature related to energy-saving using PCM in the building component. Jangeldinov et al. [119] conducted a study on the implementation of PCM in a residential building constructed from lightweight steel. Eight different cities having a warm summer humid continental climate were selected. The maximum temperature reduction was $3.31^{\circ} \mathrm{C}$ in the PCM implemented lightweight steel structure. The integration of PCM into the building framework saved the annual energy maximum up to $391.07 \mathrm{kWh}$. Olarte et al. [120] reported that the use of PCM in floor heating system save $18 \%$ energy cost. Zhang et al. [121] emphasize the use of PCM in the building for space heating and cooling of the building. The use of PCM for space heating and cooling of buildings helps in narrowing the gap between the peak and off-peak loads of electricity demand. The PCM based structural/non-structural elements use more solar energy and reduce the cooling load of air conditioning. Sharma et al. [122] reported that the PCM selection significantly depends upon the phase transition temperature, latent heat storage, and thermal conductivity. The high latent heat per volume unit PCM requires a lesser physical size of heat storage. Further, high thermal conductivity assists in the timely charging and discharging of energy storage upon demand. These findings present a benefit of using PCM in the building for promoting renewable energy consumption. The space heating and solar thermal applications described in indicators 7.1.2 and 7.2.1 reflect the strong connection between the PCM concrete composite/PCMs with the UN SDGs 7.

Additionally, indicator 7.a.1 about clean energy research and development depicts the section of solar energy research and emphasizes solar thermal applications and solar heating. Therefore, PCM also helps to attain indicator 7.a.1. Furthermore, the application of PCM in buildings for thermal comfort indirectly supports indicator 7.b.1. This indicator refers to the installed capacity of power plants that generate electricity from renewable energy sources divided by the total population of a country. The increase in use of PCM as a building material decreases fossil-fuel energy-based HVAC practices, indirectly supporting the reduction of the global energy demand. It can be observed that PCM and passive building envelopes could be a larger supplier of clean energy in the building sector for the achievement of the 2030 targets.

It should be noted here that the use of PCM in infrastructure development is also compatible with the target achievement of SDGs 9, 11, and 12 through its contribution. The possible impact of PCM usage on the traditional practices associated with buildings is comprehensively discussed in the next section.

\subsection{Impact of PCM Usage on the Stages of Building Life Spans and Mapping with SDGs}

A concrete composite must pass through various stages (architectural planning, material selection, planning and execution, repair and rehabilitation, construction and demolition) associated with the building lifetime. These stages are considered traditional infrastructure practices for the efficient use of concrete. However, the use of PCM into concrete as a thermal energy storage material affects these traditional practices, as tailored PCM-incorporated concrete may have different mixing and handling procedures. In ad- 
dition, the durability of PCM-incorporated concrete is still in the early phase of research. Furthermore, the energy efficient repair and demolition strategies of PCM-incorporated concrete may receive much attention in the future. Therefore, the mapping of PCMincorporated concrete considering the various stages of building lifetimes with the UN SDGs is a motivational source for researchers to pursue their research on the challenging issues related to this concrete that continue to hinder its use in field applications. Figure 10 shows the various construction stages that will be affected after the large-scale application of PCM-containing concrete in the field and the mapping with the different UN SDGs.

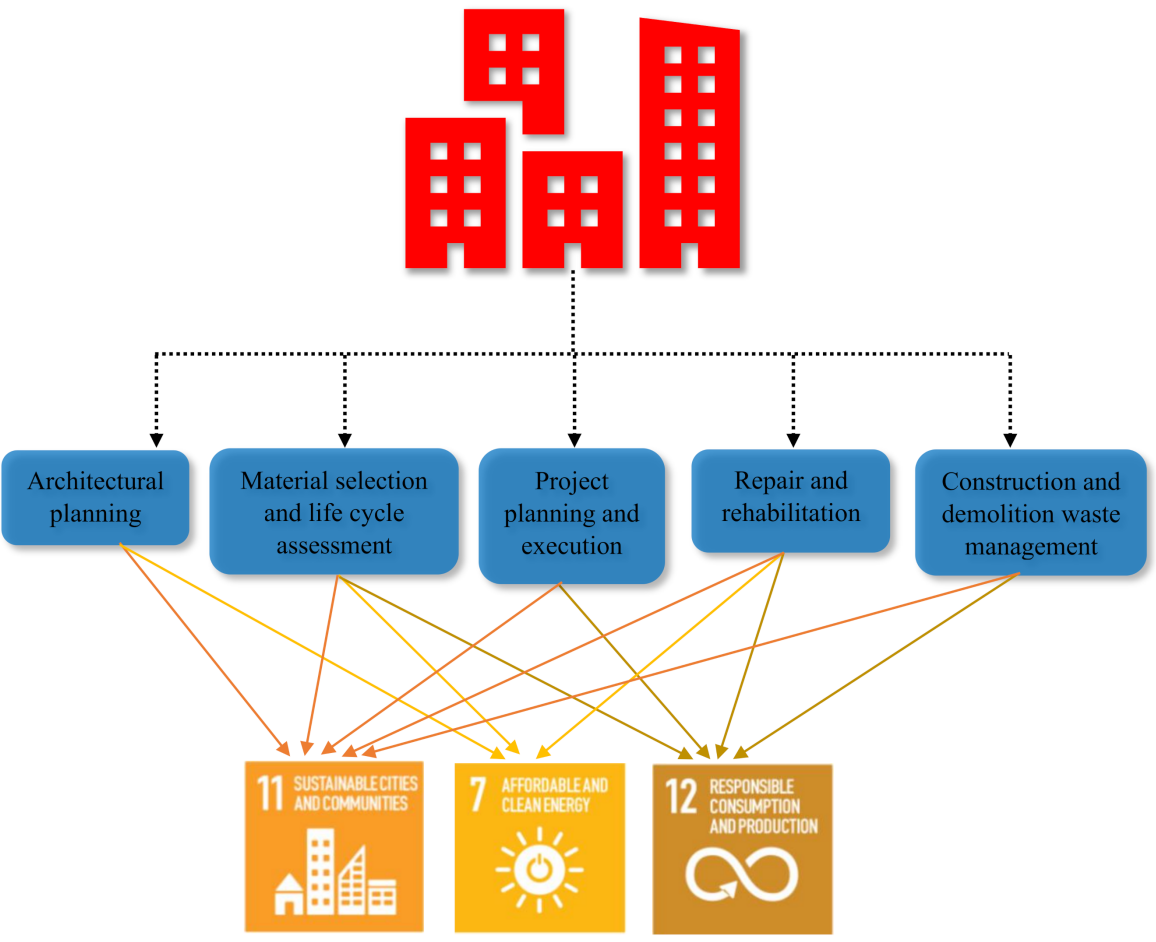

Figure 10. Mapping of various construction stages with UN sustainable development goals after considering the use of PCM in concrete.

The architectural planning of a net-zero energy building meets UN SDGs 7 (affordable and clean energy) and 11 (sustainable communities and cities), as shown in Figure 10. The improvement in the energy efficiency of a building via the optimized design of building elements, shape, and geometry was also reported [123]. The energy-efficient walls such as Trombe walls, autoclaved aerated concrete (AAC) walls, double skin walls, and green walls were tested for their effect on the overall energy efficiency of the building [124]. For instance, the Trombe wall stores the solar thermal energy during the day and releases it inside the building overnight [125]. Odunfa et al. [126] investigated the effect of the orientation of a building on the energy demand. The north-south facing of the building was the most beneficial orientation for reducing the energy demand. The building oriented towards East-West shows the increase in energy demand. Raof [127] reported that the horizontal curve shape of buildings is equivalent to rectangular shape building and better than the vertical curve in cooling load. However, the architectural planning of PCMincorporated infrastructure requires somewhat of a different approach than those used in the traditional practices due to certain limitations. The use of PCM in concrete can limit the freedom of concrete utilization under an adverse environment, special structural applications and complicate its placement in skeleton-like structure elements. The use of PCM increases the thermal inertia of the construction materials [128]. Therefore, the proportion of energy storage through PCM incorporation and sustainable infrastructure practices such as the orientation of the building, the geometry/shape, the window-to-wall 
area ratio, and shading devices for passive cooling and heating of the building envelope using solar energy [129-135] all need to be maintained.

Zang and Zang [136] conducted a study that compared the embodied emissions by different structural schemes considering the same building design of a residential building. Brick masonry, hollow block masonry, reinforced concrete frames, and reinforced concrete wall structures were analyzed. It was reported that the reinforced masonry and concrete frame structures were considerable options to control the embodied emissions. Additionally, hollow block masonry structures could be a good option for buildings in non-seismic regions considering their relatively low project costs and emissions. In terms of energy-saving building elements, double-skin facades (DSF) enable the separation of two surfaces with an air cavity. The DSF shows efficiency in maintaining high thermal comfort for occupants, but the efficiency is significantly altered depending on the type of window glazing, the design of the cavities, and the flows of air between them [137-139]. In addition, the use of effective electronic controllers, their installation at different locations can also help to maximize the use of renewable energy, consequently making life healthier for the user. However, it remains a concerning area of development for the building software development industry to create a virtual 3D model fully able to show a complete operational building. Simultaneously, the software calculates the energy costs along with local environmental factors. Therefore, it is challenging for the architects to promote the use of PCM-incorporated concrete on a large scale in the absence of authenticated data related to performance comparisons between this type of concrete and other available options in terms of strength, thermal energy storage, and durability performance. Research related to the long-term performance of PCM-incorporated concrete and the corresponding functions and interactions with the surrounding environment will support architects in their efforts to promote the use of PCM based on the structure type and local environmental conditions.

The material selection and life cycle assessment stages of infrastructure practices help to achieve UN SDGs 7, 11, and 12. However, the use of PCM as a building material in the infrastructure practices can lead to some interaction with the binding materials and can alter the fresh, mechanical and durability properties, as indicated in Table 2 [140]. PCM has been successfully applied in wallboards to store high levels of thermal energy in a building [23]. However, the incorporation of PCM into concrete remains a challenge, e.g., paraffin-based PCMs exhibit good stability and resist degradation in high $\mathrm{pH}$ environments, but are non-polar in nature; therefore, their bonding with concrete hydration products is not possible [141]. This observation significantly affects the material selection stage and its method of use in concrete. In addition, the scarcity of data on the durability and life cycle assessments of various types of PCM-containing concrete represents a massive challenge to those seeking to adopt this material in an actual project.

The execution of a building project with traditional practices is no longer sustainable due to governmental and non-government policies and given that society is concerned with sustainable practices of the construction industry [142]. The planning and execution stages are shifting towards optimum resource utilization, reduced waste generation, and lower $\mathrm{CO}_{2}$ emissions during the construction stages [143]. Therefore, the project planning and execution are mapped with UN SDGs 11 and 12. In the future, the use of PCM as a thermal energy storage material requires intense planning and execution skills, e.g., the handling and storage of PCM, skilled manpower at PCM concrete worksites, and quality assurances of PCM-concrete composites.

Achieving the decarbonization of energy use in the building sector requires almost all existing buildings to undergo a single in-depth retrofit by 2050, and new construction to meet stringent efficiency standards. Building energy codes covering new and existing buildings are a fundamental policy instrument to drive such changes. These energy codes are slated to be implemented in all regions by 2030 [144]. Thus, this implies an upcoming shift in the retrofitting of buildings, not only the strength upgrades but also towards net-zero carbon-ready buildings (ZCRB). ZCRB means that the buildings meet zero-carbon-ready building's energy codes. Figure 11 shows that over $85 \%$ of the buildings are the ZCRB type 
with reduced levels of demand for heating and cooling by 2050. Hence, the application of PCM to upcoming building retrofitting projects for energy-efficient retrofitting cannot be ignored. PCM can be implemented in the built environment to raise the existing buildings category and transform them into a greener category of infrastructure. The integrated use of sustainable concrete and PCM to reduce $\mathrm{CO}_{2}$ emissions and the maximum utilization of thermal energy for heating and cooling purposes in buildings can be the future scope to attain the UN SDGs 7 (affordable and clean energy), 11 (sustainable communities and cities) and 12 (responsible consumption and production). However, comprehensive research is required to analyze the contributions of PCMs to energy-efficient retrofitting efforts to transform an existing structure into ZCRD structures.

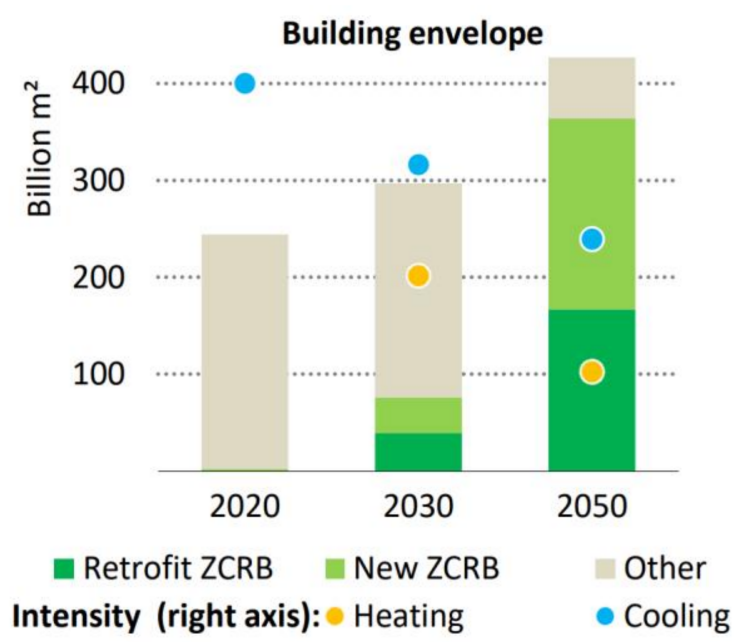

Figure 11. Targeted retrofitting of existing building to achieve zero carbon ready building and upcoming building following the zero-carbon-ready building energy codes (IEA, All right reserved) [128].

The last stage associated with the building life is demolition and waste management. Table 3 shows the top nine countries' demolition waste production with their population size and economic activities of the country. Furthermore, the evidence indicates that the construction industry generates approximately $44 \%$ of landfill waste in the United Kingdom, 44\% in Australia, 40\% in Brazil, 29\% in the United States, 27\% in Canada, and $25 \%$ in Hong Kong [145].

Table 3. C\&DW generation worldwide $[145,146]$.

\begin{tabular}{lccccc}
\hline ID & Country & $\begin{array}{c}\text { C\&DW Generation } \\
\text { (Million Tonnes) }\end{array}$ & Area (km $\mathbf{~}^{\text {) }}$ & $\begin{array}{c}\text { Population } \\
\text { 2018 (Million) }\end{array}$ & $\begin{array}{c}\text { GDP 2018 } \\
\text { (Billion USD) }\end{array}$ \\
\hline 1 & Hong Kong & 20 & 1050 & 7.4 & 363 \\
2 & Australia & 20.4 & $7,692,020$ & 25 & 1434 \\
3 & Netherlands & 22 & 33,690 & 17.2 & 914 \\
4 & Italy & 39 & 294,140 & 60.5 & 2084 \\
5 & United Kingdom & 58 & 241,930 & 66.5 & 2855 \\
6 & France & 65 & 547,557 & 67 & 2778 \\
7 & Germany & 86 & 349,360 & 83 & 3948 \\
8 & United States & 534 & $9,147,420$ & 327 & 20,544 \\
9 & China & 1130 & $9,388,210$ & 1393 & 13,608 \\
\hline
\end{tabular}

However, demolished waste consists of traditional components of concrete, steel, wood, and electric waste thus far. However, as PCMs used in infrastructure, soon demolition materials will contain PCM-concrete composites. This waste may affect the existing waste concrete reuse practice, such as the recycling of concrete paste and aggregate materials. The interaction between PCMs and concrete degrades the hydration products of concrete paste and may reveal new challenges when attempting to recycle this concrete. 
Thus far, no study has been conducted to assess the properties of concrete prepared using PCM-containing waste concrete material as a filler material.

Based on the above discussion, it can be concluded that every segment of the building process correlates with the environmental protection practices as recommended by the UN SDGs. Consequently, the weight/attention to think, plan, procure material, execute the project and supervise to attain durability, repair and retrofitting not only to achieve strength, but also for higher sustainability, to reduce the carbon footprint, and for the effective management of the construction and demolition waste management stages has increased. The reason for the increased weighting in each of the construction activities is due to the introduction of energy-efficient materials. Additionally, the outcomes of infrastructure and urban development for each country are now going to be measured in terms of the reduction of the carbon footprint and embodied energy. However, the regular practice of handling thermally efficient concrete for building construction will provide experience to practitioners associated with the different stages of building lifetimes, thus reducing the time required to make a zero-carbon-ready building fully functional.

\section{Techniques for the Safe Deposit of PCM in Concrete for Large-Scale Applications}

Presently, PCM-incorporated concrete is in the research and development stage. The work thus far on PCM has revealed the strength degradation of PCM-integrated mortar/concrete compared to that of normal mortar/concrete, as shown in Table 2. Overcoming the strength degradation issue of building materials using PCM is still a challenge. Another issue is long-term cyclic stability, which needs extensive research to establish PCM incorporation into the concrete/mortar as a durable option [147]. Due to the scarcity of sufficient research data, no technical guidelines related to PCM usage in concrete have been documented.

However, certain recent attempts, such as the coating of PCM containing LWA, the use of nanomaterials in PCMs, pipes filled with PCM, the use of supplementary cementitious materials in concrete to overcome the degradation effect of PCM, and PCM impregnation into concrete pores from the surface, all show performance improvements of PCM-containing concrete [91,148,149]. Jafarabad et al. [28] reported that the compressive strength was improved by $25 \%$ by using the silica fume in a cement matrix and polyethylene glycol as a PCM compared to a specimen without silica fume. Le et al. [150] revealed that the coating on PCM containing LWA with cement is an efficient method to improve the performance of concrete. Cement is chemically compatible with the bond development between the PCM host material and the paste phase. Therefore, the use of SCM or cement is better than the other types of coating materials. Royon et al. [151] reported an efficient method of increasing the thermal mass of buildings using a safe deposit of PCM in eight cylindrical holes of a concrete slab. Similarly, PCM deposited into PVC pipes and then embedded into the concrete pavement is an efficient technique to improve the performance of concrete [152]. Haider et al. [91] investigated the interaction of low-temperature phase change material with concrete prepared with lightweight aggregate. The normal aggregate was replaced with 50\% and 100\% epoxy coated and PCM impregnated lightweight aggregate. The compressive strength corresponding to $50 \%$ and $100 \%$ replacement was decreased by $28.94 \%$ and $38.82 \%$, respectively, as compared to the control specimen. Furthermore, silica fume and carbon nanotubes have been added to the concrete to improve the properties of the paste phase. It was found that the addition of silica fume and carbon nanotube regain the strength by $13.30 \%$ in the case of $50 \%$ PCM-LWA mix and $18.82 \%$ in 100\% PCM-LWA mix.

All of the aforementioned techniques are improvements over the direct inclusion of PCM in concrete and consequently imparts more reliability with regard to product performance outcomes in terms of the mechanical and durability properties. These properties are the foremost requirements for novel concrete composite products for large-scale applications. The large-scale application of PCM concrete composites will better serve the UN SDGs by using renewable energy. In addition to these assessments of the field experimental 
reliability of PCMs, the development of building modeling software that can handle the maximum parameters (e.g., humidity factor, outdoor temperature in different climates, the contribution of solar renewable systems with various types of solar energy, integrated modeling using PCM passive systems with natural night ventilation) to provide a unified solution for predicting the maximum benefits of using green materials and renewable energy still requires more effort regarding its hands-on use. Furthermore, direct evaluations of the output of building modeling scores with UN SDG infrastructure-related targets can be helpful to align the practitioner towards the measurement of the conservation of energy.

\section{Current Challenges and Future Perspectives}

Considering the positive impact of the use of PCM in building materials, the researchers are putting efforts on the more safe, durable, and reduction on the negative effect of PCM on the concrete mechanical properties. The following challenges limit the widespread use of PCM in concrete on field projects.

\subsection{Thermal Performance of PCM}

The low thermal conductivity of PCM decreases the rate of heat-absorbing/releasing during the phase change operation. Specifically, low thermal conductivity PCM is ineffective in energy storage when the temperature changes rapidly [147]. Additionally, the full potential of PCM is not utilized due to the increase of charging and discharging time of PCM [153]. The use of carbon foam, metal foam, layered clay minerals such as kaolin, carbon fibers, carbon nanotube, and nanoparticles to enhance the thermal conductivity of PCM have been reported in the past. The copper nanoparticles were dispersed into paraffin wax to improve the thermal conductivity. The size of the copper nanoparticle was $20 \mathrm{~nm}$. The maximum increase in synthesized copper-PCM was $46.3 \%$ when $2.0 \mathrm{wt} . \%$ of copper nanoparticles were dispersed in the PCM. The copper nanoparticles were also acted as a nucleation agent and reduced the supercooling effect during the phase change process [154]. The carbon-based additives were also added to the PCM to improve the thermal conductivity. The thermal conductivity of PCM increased up to 12 times when $5 \mathrm{wt} . \%$ graphite was added to the PCM [155]. However, the improvement in thermal conductivity of PCM is still in the research and development stage, and most of the PCM used in the infrastructure-related research is primarily from the family of paraffin wax and fatty acids. Therefore, the lack of data in the literature is available regarding the interaction of synthesized PCM with the cement matrix.

\subsection{Trade-Off between Concrete Performance and PCM}

Various literature reported that the concrete strength starts decreasing with the increment of PCM dosage in concrete [105,156-160]. The extent of strength degradation depends upon the method by which the PCM is incorporated in the concrete. Therefore, the direct incorporation of PCM in concrete is an obsolete method. To avoid the direct interaction between the PCM and concrete matrix, the porous aggregate filled with PCM and coated with epoxy is the feasible method of reducing the negative effect of PCM on the strength of concrete [161]. However, the building components primarily functioning as heat storage devices and strength is the secondary criteria such as wallboard, ceiling tiles, and floor panels, the use of PCM is successfully implemented [162]. These building components act as a non-structural component and the minimum performance requirement described by the ASCE 7 [163] is mandatory to achieve the operational performance of the building after an earthquake [164]. The failure of non-structural components disturbed the overall functioning of the building. The cost and time involved in the rehabilitation of the building are other important factors. Therefore, the seismic certification of PCM contained non-structural components is the current challenge. 


\subsection{Link between the Outcome of PCM Based Building Materials and UN SDGs}

The SDG Report 2021 [165] reported that the annual energy efficiency improvement rate was $2 \%$ from 2010 to 2018 . The required energy efficiency improvement rate is $3 \%$ to attain the targets for the 2018 to 2030 period. The report also emphasized the significant efforts are required on the safe and wide acceptability of modern renewable energy, especially in the heating and transport sectors. The share of renewable energy is increased by $4.27 \%$ in 2018 compared to the data of 2010. Presently, the electricity used in a building for heating and cooling space is primarily dependent on fossil fuels. However, the PCM uses renewable energy in buildings for heating and cooling purpose and decreasing fossil fuel- based electricity consumption. The methodology to reveal a link between PCM-based building materials outcomes and UN SDGs is not established so far. The direct measurement of the reduction in consumption of fossil fuel-based electricity after using the PCM products in a building from the field projects will motivate the policymaker, engineer, and society. The measurement of the outcome of PCM-based building materials helps architects and design engineers to directly measure and visualize the effectiveness of their selected building design and material selection contribution in the attainment of UN SDGs.

\section{Conclusions}

The present study reviews the PCM and its application in two aspects. The first aspect is the PCM type, properties, its application in the concrete, and the associated challenges of using PCM in concrete. The second aspect is the contribution of PCM-concrete composite to the UN SDGs.

Supplementary cementitious material and epoxy coated lightweight aggregate exhibit a safe deposit of PCM in concrete. The use of nanomaterials and silica fume in concrete recover the strength reduction of PCM concrete composites. The improvement in the paste phase using nanomaterials and silica fume is the cause of strength recovery. For the successful field application of PCM concrete composites, the trade-off between mechanical and thermal storage property remains a challenge for researchers. Quality assurance of composite matrixes by the complete elimination of PCM leakages into the matrix, good long-term cyclic stability, and a negligible negative effect on the compressive strength remain open and highly complicated areas of research.

PCM used in concrete can significantly contribute to the attainment of UN SDG 7 globally. The efforts have been made to map the available parameters (targets and indicators) present in the UN SGDs with the benefits of using PCM in concrete for infrastructure development. The complete lifespan of buildings is divided into five different stages (planning, material procurement, execution, repair and retrofitting, and construction and demolition waste). The contribution of each stage when using PCMs to the infrastructure-related UN SDGs 7,11 , and 12 is extensively presented. Undoubtedly, more scientific measurements are required to deliver a firm connection between PCM concrete composites and the UN SDGs.

In a nutshell, it can be concluded that the application of PCM on a large scale during the different levels of the building construction process has significant potential to achieve net-zero-ready buildings and can thus strongly contribute to the realization of the UN SDGs. This study disseminates the awareness of the PCM in the UN SDGs attainment on a global scale to the research community.

Author Contributions: R.S.: conceptualization; methodology; writing-original draft; writingreview and editing. J.-G.J.: conceptualization; funding acquisition; project administration; supervision; resource; writing-review and editing. J.-W.H.: funding acquisition; project administration; supervision; resource; writing-review and editing. All authors have read and agreed to the published version of the manuscript.

Funding: This work was supported by the Materials and Components Technology Development Program (20015240, Development of micro-phase change material (PCM) manufacturing technology and heat-generating concrete for heating energy saving using the same) funded By the Ministry of 
Trade, Industry \& Energy (MOTIE, Korea). This work was also supported by the Research Assistance Program (2021) in the Incheon National University, Korea.

Institutional Review Board Statement: Not applicable.

Informed Consent Statement: Not applicable.

Data Availability Statement: Data is contained within the article.

Conflicts of Interest: The authors declare no conflict of interest. The funders had no role in the design of the study; in the collection, analyses, or interpretation of data; in the writing of the manuscript, or in the decision to publish the results.

\section{References}

1. Sharma, R.; Bansal, P.P. Behavior of RC exterior beam column joint retrofitted using UHP-HFRC. Constr. Build. Mater. 2019, 195, 376-389. [CrossRef]

2. Etri, C. China Energy Outlook; CNPC Economics and Technology Research Institute: Tokyo, Japan, 2018. [CrossRef]

3. Singh, R.; Ravache, B.; Sartor, D. Building Innovation: A Guide for High-Performance Energy Efficient Buildings in India; Lawrence Berkeley National Laboratoy: Berkeley, NJ, USA, 2018; Volume 199.

4. IEA (2012), World Energy Outlook 2012, IEA, Paris. Available online: https://www.iea.org/reports/world-energy-outlook-2012 (accessed on 12 November 2021).

5. Agency, I.E. Energy Technology Perspectives 2017-Catalysing Energy Technology Transformations; International Energy Agency: Paris, France, 2017. [CrossRef]

6. Chel, A.; Kaushik, G. Renewable energy technologies for sustainable development of energy efficient building. Alexandria Eng. J. 2018, 57, 655-669. [CrossRef]

7. IIEA; UNEP. Global Status Report for Buildings and Construction; International Energy Agency: Paris, France, 2019.

8. IEA Building Envelopes, IEA, Paris. Available online: https://www.iea.org/reports/building-envelopes (accessed on 25 August 2021).

9. Sachs, J.D. Achieving the Sustainable Development Goals. J. Int. Bus. Ethics 2015, 8, 53-62. [CrossRef]

10. UNOPS. The critical role of infrastructure for the Sustainable Development Goals. Econ. Intell. Unit Ltd. 2019 2019, 25, 1-22.

11. Bennett, J.; Baker, A.; Johncox, E.; Nateghi, R. Characterizing the key predictors of renewable energy penetration for sustainable and resilient communities. J. Manag. Eng. 2020, 36, 04020016. [CrossRef]

12. Ali, K.A.; Ahmad, M.I.; Yusup, Y. Issues, impacts, and mitigations of carbon dioxide emissions in the building sector. Sustainability 2020, 12, 7427. [CrossRef]

13. Hughes, B.R.; Mak, C.M. A study of wind and buoyancy driven flows through commercial wind towers. Energy Build. 2011, 43, 1784-1791. [CrossRef]

14. Hughes, B.R.; Calautit, J.K.; Ghani, S.A. The development of commercial wind towers for natural ventilation: A review. Appl. Energy 2012, 92, 606-627. [CrossRef]

15. Shaikh, P.H.; Nor, N.B.M.; Nallagownden, P.; Elamvazuthi, I.; Ibrahim, T. A review on optimized control systems for building energy and comfort management of smart sustainable buildings. Renew. Sustain. Energy Rev. 2014, 34, 409-429. [CrossRef]

16. Taleb, H.M. Using passive cooling strategies to improve thermal performance and reduce energy consumption of residential buildings in U.A.E. buildings. Front. Archit. Res. 2014, 3, 154-165. [CrossRef]

17. Bhamare, D.K.; Rathod, M.K.; Banerjee, J. Passive cooling techniques for building and their applicability in different climatic zones-The state of art. Energy Build. 2019, 198, 467-490. [CrossRef]

18. Cabeza, L.F.; de Gracia, A. Thermal energy storage (TES) systems for cooling in residential buildings. In Advances in Thermal Energy Storage Systems Methods and Applications; Woodhead publishing: Sawston, UK, 2015; pp. 549-572. [CrossRef]

19. Faraj, K.; Khaled, M.; Faraj, J.; Hachem, F.; Castelain, C. Phase change material thermal energy storage systems for cooling applications in buildings: A review. Renew. Sustain. Energy Rev. 2020, 119, 109579. [CrossRef]

20. Saffari, M.; de Gracia, A.; Ushak, S.; Cabeza, L.F. Passive cooling of buildings with phase change materials using whole-building energy simulation tools: A review. Renew. Sustain. Energy Rev. 2017, 80, 1239-1255. [CrossRef]

21. Tyagi, V.V.; Buddhi, D. PCM thermal storage in buildings: A state of art. Renew. Sustain. Energy Rev. 2007, 11, 1146-1166. [CrossRef]

22. Cui, Y.; Xie, J.; Liu, J.; Wang, J.; Chen, S. A review on phase change material application in building. Adv. Mech. Eng. 2017, 9, 1-15. [CrossRef]

23. Evola, G.; Marletta, L. The effectiveness of PCM wallboards for the energy refurbishment of lightweight buildings. Energy Procedia 2014, 62, 13-21. [CrossRef]

24. Li, D.; Zheng, Y.; Liu, C.; Wu, G. Numerical analysis on thermal performance of roof contained PCM of a single residential building. Energy Convers. Manag. 2015, 100, 147-156. [CrossRef]

25. Alawadhi, E.M. Thermal analysis of a building brick containing phase change material. Energy Build. 2008, 40, 351-357. [CrossRef]

26. Zhuang, S.; Zhang, Y.; Zhu, Q.; Yan, R.; He, J. Experimental study on the thermal response of PCM energy storage block with hole ventilation. Adv. Mater. Sci. Eng. 2015, 2015. [CrossRef] 
27. Castell, A.; Martorell, I.; Medrano, M.; Pérez, G.; Cabeza, L.F. Experimental study of using PCM in brick constructive solutions for passive cooling. Energy Build. 2010, 42, 534-540. [CrossRef]

28. Jafarabad, A.M.; Madhkhan, M.; Sharifi, N.P. Thermal and mechanical properties of PCM-incorporated normal and lightweight concretes containing silica fume. Can. J. Civ. Eng. 2019, 46, 643-656. [CrossRef]

29. Mohseni, E.; Tang, W.; Wang, S. Development of thermal energy storage lightweight structural cementitious composites by means of macro-encapsulated PCM. Constr. Build. Mater. 2019, 225, 182-195. [CrossRef]

30. Ben Romdhane, S.; Amamou, A.; Ben Khalifa, R.; Saïd, N.M.; Younsi, Z.; Jemni, A. A review on thermal energy storage using phase change materials in passive building applications. J. Build. Eng. 2020, 32, 101563. [CrossRef]

31. Sharma, A.; Tyagi, V.V.; Chen, C.R.; Buddhi, D. Review on thermal energy storage with phase change materials and applications. Renew. Sustain. Energy Rev. 2009, 13, 318-345. [CrossRef]

32. Kumar, A.; Shukla, S.K. A review on thermal energy storage unit for solar thermal power plant application. Energy Procedia 2015, 74, 462-469. [CrossRef]

33. Tatsidjodoung, P.; Le Pierrès, N.; Luo, L. A review of potential materials for thermal energy storage in building applications. Renew. Sustain. Energy Rev. 2013, 18, 327-349. [CrossRef]

34. Wei, G.; Wang, G.; Xu, C.; Ju, X.; Xing, L.; Du, X.; Yang, Y. Selection principles and thermophysical properties of high temperature phase change materials for thermal energy storage: A review. Renew. Sustain. Energy Rev. 2018, 81, 1771-1786. [CrossRef]

35. Alva, G.; Lin, Y.; Fang, G. An overview of thermal energy storage systems. Energy 2018, 144, 341-378. [CrossRef]

36. Farid, M.M.; Khudhair, A.M.; Razack, S.A.K.; Al-Hallaj, S. A review on phase change energy storage: Materials and applications. Energy Convers. Manag. 2004, 45, 1597-1615. [CrossRef]

37. Khudhair, A.M.; Farid, M.M. A review on energy conservation in building applications with thermal storage by latent heat using phase change materials. Energy Convers. Manag. 2004, 45, 263-275. [CrossRef]

38. Agyenim, F.; Hewitt, N.; Eames, P.; Smyth, M. A review of materials, heat transfer and phase change problem formulation for latent heat thermal energy storage systems (LHTESS). Renew. Sustain. Energy Rev. 2010, 14, 615-628. [CrossRef]

39. Pause, B. Phase change materials and their application in coatings and laminates for textiles. In Smart Textile Coatings and Laminates; Woodhead Publishing: Sawston, UK, 2010; pp. 236-250. [CrossRef]

40. Wang, D.; Zhang, W.; Han, B. New generation of cement-based composites for civil engineering. In New Materials in Civil Engineering; Butterworth-Heinemann: Oxford, UK, 2020; pp. 777-795. [CrossRef]

41. Amaral, C.; Vicente, R.; Marques, P.A.A.P.; Barros-Timmons, A. Phase change materials and carbon nanostructures for thermal energy storage: A literature review. Renew. Sustain. Energy Rev. 2017, 79, 1212-1228. [CrossRef]

42. Kuznik, F.; Virgone, J.; Noel, J. Optimization of a phase change material wallboard for building use. Appl. Therm. Eng. 2008, 28, 1291-1298. [CrossRef]

43. Kaygusuz, K. Experimental and theoretical investigation of latent heat storage for water based solar heating systems. Energy Convers. Manag. 1995, 36, 315-323. [CrossRef]

44. Bal, L.M.; Satya, S.; Naik, S.N. Solar dryer with thermal energy storage systems for drying agricultural food products: A review. Renew. Sustain. Energy Rev. 2010, 14, 2298-2314. [CrossRef]

45. Zeinelabdein, R.; Omer, S.; Gan, G. Critical review of latent heat storage systems for free cooling in buildings. Renew. Sustain. Energy Rev. 2018, 82, 2843-2868. [CrossRef]

46. Voronin, D.V.; Ivanov, E.; Gushchin, P.; Fakhrullin, R.; Vinokurov, V. Clay composites for thermal energy storage: A review. Molecules 2020, 25, 1504. [CrossRef]

47. Pielichowska, K.; Pielichowski, K. Phase change materials for thermal energy storage. Prog. Mater. Sci. 2014, 65, 67-123. [CrossRef]

48. Verma, P.; Varun; Singal, S.K. Review of mathematical modeling on latent heat thermal energy storage systems using phase-change material. Renew. Sustain. Energy Rev. 2008, 12, 999-1031. [CrossRef]

49. Abhat, A. Low temperature latent heat thermal energy storage: Heat storage materials. Sol. Energy 1983, 30, 313-332. [CrossRef]

50. Ling, T.C.; Poon, C.S. Use of phase change materials for thermal energy storage in concrete: An overview. Constr. Build. Mater. 2013, 46, 55-62. [CrossRef]

51. Shukla, A.; Buddhi, D.; Sawhney, R.L. Thermal cycling test of few selected inorganic and organic phase change materials. Renew. Energy 2008, 33, 2606-2614. [CrossRef]

52. Sarier, N.; Onder, E. Organic phase change materials and their textile applications: An overview. Thermochim. Acta 2012, 540, 7-60. [CrossRef]

53. Jegadheeswaran, S.; Pohekar, S.D.; Kousksou, T. Conductivity particles dispersed organic and inorganic phase change materials for solar energy storage-an exergy based comparative evaluation. Energy Procedia 2012, 14, 643-648. [CrossRef]

54. Wang, T.; Mantha, D.; Reddy, R.G. Novel low melting point quaternary eutectic system for solar thermal energy storage. Appl. Energy 2013, 102, 1422-1429. [CrossRef]

55. Trisnadewi, T.; Putra, N. Phase change material (PCM) with shaped stabilized method for thermal energy storage: A review. AIP Conf. Proc. 2020, 2255. [CrossRef]

56. Jelle, B.P.; Kalnæs, S.E. Phase Change Materials for Application in Energy-Efficient Buildings. Cost-Eff. Energy Effic. Build. Retrofit. Mater. Technol. Optim. Case Stud. 2017, 57-118. [CrossRef] 
57. Sudhakar, K.; Naryana Reddy, N.; Jayaramudu, T.; Jayaramudu, J.; Reddy, A.B.; Manjula, B.; Sadiku, E.R. Aerogels and Foamed Nanostructured Polymer Blends. In Design and Applications of Nanostructured Polymer Blends and Nanocomposite Systems; William Andrew: Norwich, NY, USA, 2016; pp. 75-99.

58. Dincer, I. Comprehensive Energy Systems; Elsevier: Amsterdam, The Netherlands, 2018.

59. Zalba, B.; Marín, J.M.; Cabeza, L.F.; Mehling, H. Review on thermal energy storage with phase change: Materials, heat transfer analysis and applications. Appl. Therm. Eng. 2003, 23, 251-283. [CrossRef]

60. Safari, A.; Saidur, R.; Sulaiman, F.A.; Xu, Y.; Dong, J. A review on supercooling of phase change materials in thermal energy storage systems. Renew. Sustain. Energy Rev. 2017, 70, 905-919. [CrossRef]

61. Sun, G.; Zhang, Z. Mechanical properties of melamine-formaldehyde microcapsules. J. Microencapsul. 2001, 18, 593-602. [CrossRef] [PubMed]

62. Rahman, A.; Dickinson, M.E.; Farid, M.M. Microencapsulation of a PCM through membrane emulsification and nanocompressionbased determination of microcapsule strength. Mater. Renew. Sustain. Energy 2012, 1, 4. [CrossRef]

63. Atinafu, D.G.; Dong, W.; Huang, X.; Gao, H.; Wang, G. Introduction of organic-organic eutectic PCM in mesoporous N-doped carbons for enhanced thermal conductivity and energy storage capacity. Appl. Energy 2018, 211, 1203-1215. [CrossRef]

64. Hasnain, S.M. Review on sustainable thermal energy storage technologies, part I: Heat storage materials and techniques. Energy Convers. Manag. 1998, 39, 1127-1138. [CrossRef]

65. Singh, P.; Sharma, R.K.; Ansu, A.K.; Goyal, R.; Sarı, A.; Tyagi, V.V. A comprehensive review on development of eutectic organic phase change materials and their composites for low and medium range thermal energy storage applications. Sol. Energy Mater. Sol. Cells 2021, 223, 110955. [CrossRef]

66. Baetens, R.; Jelle, B.P.; Gustavsen, A. Phase change materials for building applications: A state-of-the-art review. Energy Build. 2010, 42, 1361-1368. [CrossRef]

67. Casini, M. Smart Buildings-Advanced Materials and Nanotechnology to Improve Energy-Efficiency and Environment Performance; Woodhead Publishing: Sawston, Cambridge, UK, 2016; pp. 107-125.

68. Mert, M.S.; Mert, H.H.; Sert, M. Microencapsulated oleic-capric acid/hexadecane mixture as phase change material for thermal energy storage. J. Therm. Anal. Calorim. 2019, 136, 1551-1561. [CrossRef]

69. Warzoha, R.J.; Fleischer, A.S. Effect of carbon nanotube interfacial geometry on thermal transport in solid-liquid phase change materials. Appl. Energy 2015, 154, 271-276. [CrossRef]

70. Wang, J.; Xie, H.; Xin, Z. Thermal properties of heat storage composites containing multiwalled carbon nanotubes. J. Appl. Phys. 2008, 104. [CrossRef]

71. Waqas, A.; Ud Din, Z. Phase change material (PCM) storage for free cooling of buildings-A review. Renew. Sustain. Energy Rev. 2013, 18, 607-625. [CrossRef]

72. Banu, D.; Feldman, D.; Hawes, D. Evaluation of thermal storage as latent heat in phase change material wallboard by differential scanning calorimetry and large scale thermal testing. Thermochim. Acta 1998, 317, 39-45. [CrossRef]

73. Scalat, S.; Banu, D.; Hawes, D.; Paris, J.; Haghighata, F.; Feldman, D. Full scale thermal testing of latent heat storage in wallboard. Sol. Energy Mater. Sol. Cells 1996, 44, 49-61. [CrossRef]

74. Martínez, A.; Carmona, M.; Cortés, C.; Arauzo, I. Characterization of thermophysical properties of phase change materials using unconventional experimental technologies. Energies 2020, 13, 4687. [CrossRef]

75. Kenisarin, M.; Mahkamov, K. Salt hydrates as latent heat storage materials:Thermophysical properties and costs. Sol. Energy Mater. Sol. Cells 2016, 145, 255-286. [CrossRef]

76. Mohamed, S.A.; Al-Sulaiman, F.A.; Ibrahim, N.I.; Zahir, M.H.; Al-Ahmed, A.; Saidur, R.; Yılbaş, B.S.; Sahin, A.Z. A review on current status and challenges of inorganic phase change materials for thermal energy storage systems. Renew. Sustain. Energy Rev. 2017, 70, 1072-1089. [CrossRef]

77. Khan, Z.; Khan, Z.; Ghafoor, A. A review of performance enhancement of PCM based latent heat storage system within the context of materials, thermal stability and compatibility. Energy Convers. Manag. 2016, 115, 132-158. [CrossRef]

78. Feldman, D.; Shapiro, M.M.; Banu, D. Organic phase change materials for thermal energy storage. Sol. Energy Mater. 1986, 13, 1-10. [CrossRef]

79. Sari, A. Eutectic mixtures of some fatty acids for low temperature solar heating applications: Thermal properties and thermal reliability. Appl. Therm. Eng. 2005, 25, 2100-2107. [CrossRef]

80. Su, D.; Jia, Y.; Alva, G.; Tang, F.; Fang, G. Preparation and thermal properties of n-octadecane/stearic acid eutectic mixtures with hexagonal boron nitride as phase change materials for thermal energy storage. Energy Build. 2016, 131, 35-41. [CrossRef]

81. Cabeza, L.F.; Castell, A.; Barreneche, C.; De Gracia, A.; Fernández, A.I. Materials used as PCM in thermal energy storage in buildings: A review. Renew. Sustain. Energy Rev. 2011, 15, 1675-1695. [CrossRef]

82. Liu, F.; Wang, J.; Qian, X. Integrating phase change materials into concrete through microencapsulation using cenospheres. Cem. Concr. Compos. 2017, 80, 317-325. [CrossRef]

83. Tyagi, V.V.; Kaushik, S.C.; Tyagi, S.K.; Akiyama, T. Development of phase change materials based microencapsulated technology for buildings: A review. Renew. Sustain. Energy Rev. 2011, 15, 1373-1391. [CrossRef]

84. Konuklu, Y.; Ostry, M.; Paksoy, H.O.; Charvat, P. Review on using microencapsulated phase change materials (PCM) in building applications. Energy Build. 2015, 106, 134-155. [CrossRef] 
85. Giro-Paloma, J.; Martínez, M.; Cabeza, L.F.; Fernández, A.I. Types, methods, techniques, and applications for microencapsulated phase change materials (MPCM): A review. Renew. Sustain. Energy Rev. 2016, 53, 1059-1075. [CrossRef]

86. Hunger, M.; Entrop, A.G.; Mandilaras, I.; Brouwers, H.J.H.; Founti, M. The behavior of self-compacting concrete containing micro-encapsulated Phase Change Materials. Cem. Concr. Compos. 2009, 31, 731-743. [CrossRef]

87. Jawaid, M.; Khan, M.M. Polymer-Based Nanocomposites for Energy and Environmental Applications; Woodhead Publishing: Sawston, Cambridge, UK, 2018.

88. Zhang, Y.P.; Lin, K.P.; Yang, R.; Di, H.F.; Jiang, Y. Preparation, thermal performance and application of shape-stabilized PCM in energy efficient buildings. Energy Build. 2006, 38, 1262-1269. [CrossRef]

89. Cui, Y.; Xie, J.; Liu, J.; Pan, S. Review of phase change materials integrated in building walls for energy saving. Procedia Eng. 2015, 121, 763-770. [CrossRef]

90. Aguayo, M.; Das, S.; Castro, C.; Kabay, N.; Sant, G.; Neithalath, N. Porous inclusions as hosts for phase change materials in cementitious composites: Characterization, thermal performance, and analytical models. Constr. Build. Mater. 2017, 134, 574-584. [CrossRef]

91. Zeeshan, M.; Jin, X.; Sharma, R.; Pei, J. Enhancing the compressive strength of thermal energy storage concrete containing a low-temperature phase change material using silica fume and multiwalled carbon nanotubes. Constr. Build. Mater. 2022, 314, 125659. [CrossRef]

92. Sukontasukkul, P.; Sangpet, T.; Newlands, M.; Yoo, D.Y.; Tangchirapat, W.; Limkatanyu, S.; Chindaprasirt, P. Thermal storage properties of lightweight concrete incorporating phase change materials with different fusion points in hybrid form for high temperature applications. Heliyon 2020, 6, e04863. [CrossRef]

93. Jayalath, A.; San Nicolas, R.; Sofi, M.; Shanks, R.; Ngo, T.; Aye, L.; Mendis, P. Properties of cementitious mortar and concrete containing micro-encapsulated phase change materials. Constr. Build. Mater. 2016, 120, 408-417. [CrossRef]

94. Du, Y.; Liu, P.; Quan, X.; Ma, C. Characterization and cooling effect of a novel cement-based composite phase change material. Sol. Energy 2020, 208, 573-582. [CrossRef]

95. Hunger, M.; Entrop, A.G.; Mandilaras, I.; Brouwers, H.J.H.; Founti, M. The direct incorporation of micro-encapsulated Phase Change Materials in the concrete mixing process-A feasibility study. In Proceedings of the CIB W115 Construction Materials Stewardship, Enschede, The Netherlands, 12-15 June 2009; pp. 141-148. Available online: https:// citeseerx.ist.psu.edu/viewdo c/download?doi=10.1.1.460.9059\&rep=rep1\&type=pdf\#page=143 (accessed on 3 January 2021).

96. Ren, M.; Liu, Y.; Gao, X. Incorporation of phase change material and carbon nanofibers into lightweight aggregate concrete for thermal energy regulation in buildings. Energy 2020, 197, 117262. [CrossRef]

97. Soares, N.; Costa, J.J.; Gaspar, A.R.; Santos, P. Review of passive PCM latent heat thermal energy storage systems towards buildings' energy efficiency. Energy Build. 2013, 59, 82-103. [CrossRef]

98. Marani, A.; Nehdi, M.L. Integrating phase change materials in construction materials: Critical review. Constr. Build. Mater. 2019, 217, 36-49. [CrossRef]

99. Kusumadhar, S.; Das, B.B. Effect of phase-change materials on the hydration and mineralogy of cement mortar. Proc. Inst. Civ. Eng. Constr. Mat. 2020,1-11. [CrossRef]

100. Sakulich, A.R.; Bentz, D.P. Incorporation of phase change materials in cementitious systems via fine lightweight aggregate. Constr. Build. Mater. 2012, 35, 483-490. [CrossRef]

101. Memon, S.A. Phase change materials integrated in building walls: A state of the art review. Renew. Sustain. Energy Rev. 2014, 31, 870-906. [CrossRef]

102. $\mathrm{Xu}, \mathrm{B} . ; \mathrm{Li}, \mathrm{Z}$. Paraffin/diatomite composite phase change material incorporated cement-based composite for thermal energy storage. Appl. Energy 2013, 105, 229-237. [CrossRef]

103. Tang, W.; Wang, Z.; Mohseni, E.; Wang, S. A practical ranking system for evaluation of industry viable phase change materials for use in concrete. Constr. Build. Mater. 2018, 177, 272-286. [CrossRef]

104. Liao, W.; Kumar, A.; Khayat, K.; Ma, H. Multifunctional lightweight aggregate containing phase change material and water for damage mitigation of concrete. ES Mater. Manuf. 2019, 49-61. [CrossRef]

105. Gürbüz, E.; Erdem, S. Development and thermo-mechanical analysis of high-performance hybrid fibre engineered cementitious composites with microencapsulated phase change materials. Constr. Build. Mater. 2020, 263, 120139. [CrossRef]

106. Ren, M.; Wen, X.; Gao, X.; Liu, Y. Thermal and mechanical properties of ultra-high performance concrete incorporated with microencapsulated phase change material. Constr. Build. Mater. 2021, 273, 121714. [CrossRef]

107. Mohseni, E.; Tang, W.; Wang, Z. Structural-functional integrated concrete with macro-encapsulated inorganic PCM. AIP Conf. Proc. 2017, 1884, 030002. [CrossRef]

108. Memon, S.A.; Cui, H.; Lo, T.Y.; Li, Q. Development of structural-functional integrated concrete with macro-encapsulated PCM for thermal energy storage. Appl. Energy 2015, 150, 245-257. [CrossRef]

109. Dong, Z.; Cui, H.; Tang, W.; Chen, D.; Wen, H. Development of hollow steel ball macro-encapsulated PCM for thermal energy storage concrete. Materials 2016, 9, 59. [CrossRef]

110. Vicente, R.; Silva, T. Brick masonry walls with PCM macrocapsules: An experimental approach. Appl. Therm. Eng. 2014, 67, 24-34. [CrossRef]

111. Nomura, T.; Okinaka, N.; Akiyama, T. Impregnation of porous material with phase change material for thermal energy storage. Mater. Chem. Phys. 2009, 115, 846-850. [CrossRef] 
112. Ramakrishnan, S.; Wang, X.; Sanjayan, J.; Wilson, J. Thermal energy storage enhancement of lightweight cement mortars with the application of phase change materials. Procedia Eng. 2017, 180, 1170-1177. [CrossRef]

113. Kim, H.G.; Qudoos, A.; Jeon, I.K.; Woo, B.H.; Ryou, J.S. Assessment of PCM/SiC-based composite aggregate in concrete: Energy storage performance. Constr. Build. Mater. 2020, 258, 119637. [CrossRef]

114. Williams, A.; Whiteman, G.; Parker, J.N. Backstage interorganizational collaboration: Corporate endorsement of the sustainable development goals. Acad. Manag. Discov. 2019, 5, 367-395. [CrossRef]

115. Kumar, P.; Ahmed, F.; Singh, R.K.; Sinha, P. Determination of hierarchical relationships among sustainable development goals using interpretive structural modeling. Environ. Dev. Sustain. 2018, 20, 2119-2137. [CrossRef]

116. Tyagi, R.; Vishwakarma, S.; Singh, K.K.; Syan, C. Low-Cost Energy Conservation Measures and Behavioral Change for Sustainable Energy Goals; Springer: Cham, Switzerland, 2021; pp. 831-843. [CrossRef]

117. Stropnik, R.; Koželj, R.; Zavrl, E.; Stritih, U. Improved thermal energy storage for nearly zero energy buildings with PCM integration. Sol. Energy 2019, 190, 420-426. [CrossRef]

118. Mofijur, M.; Mahlia, T.M.I.; Silitonga, A.S.; Ong, H.C.; Silakhori, M.; Hasan, M.H.; Putra, N.; Ashrafur Rahman, S.M. Phase change materials (PCM) for solar energy usages and storage: An overview. Energies 2019, 12, 3167. [CrossRef]

119. Jangeldinov, B.; Memon, S.A.; Kim, J.; Kabdrakhmanova, M. Evaluating the energy efficiency of PCM-integrated lightweight steel-framed building in eight different cities of warm summer humid continental climate. Adv. Mater. Sci. Eng. 2020, 2020, 4381495. [CrossRef]

120. Mazo, J.; Delgado, M.; Marin, J.M.; Zalba, B. Modeling a radiant floor system with Phase Change Material (PCM) integrated into a building simulation tool: Analysis of a case study of a floor heating system coupled to a heat pump. Energy Build. 2012, 47, 458-466. [CrossRef]

121. Zhang, Y.; Zhou, G.; Lin, K.; Zhang, Q.; Di, H. Application of latent heat thermal energy storage in buildings: State-of-the-art and outlook. Build. Environ. 2007, 42, 2197-2209. [CrossRef]

122. Sharma, R.K.; Ganesan, P.; Tyagi, V.V.; Metselaar, H.S.C.; Sandaran, S.C. Developments in organic solid-liquid phase change materials and their applications in thermal energy storage. Energy Convers. Manag. 2015, 95, 193-228. [CrossRef]

123. Gero, J.S.; D'Cruz, N.; Radford, A.D. Energy in context: A multicriteria model for building design. Build. Environ. 1983, 18, 99-107. [CrossRef]

124. Omrany, H.; GhaffarianHoseini, A.; GhaffarianHoseini, A.; Raahemifar, K.; Tookey, J. Application of passive wall systems for improving the energy effciency in buildings: A comprehensive review. Renew. Sustain. Energy Rev. 2016, 62, 1252-1269. [CrossRef]

125. Abbassi, F.; Dimassi, N.; Dehmani, L. Energetic study of a Trombe wall system under different Tunisian building configurations. Energy Build. 2014, 80, 302-308. [CrossRef]

126. Odunfa, K.M.; Ojo, T.O.; Odunfa, V.O.; Ohunakin, O.S. Energy efficiency in building: Case of buildings at the University of Ibadan, Nigeria. J. Build. Constr. Plan. Res. 2015, 3, 18-26. [CrossRef]

127. Raof, B.Y. The correlation between building shape and building energy performance. Int. J. Adv. Res. 2017, 5, 552-561. [CrossRef]

128. Laaouatni, A.; Martaj, N.; Bennacer, R.; El Omari, M.; El Ganaoui, M. Phase change materials for improving the building thermal inertia. Energy Procedia 2017, 139, 744-749. [CrossRef]

129. Hachem-Vermette, C. Multistory building envelope: Creative design and enhanced performance. Sol. Energy 2018, 159, 710-721. [CrossRef]

130. Sozer, H. Improving energy efficiency through the design of the building envelope. Build. Environ. 2010, 45, 2581-2593. [CrossRef]

131. Hemsath, T.L. Conceptual energy modeling for architecture, planning and design: Impact of using building performance simulation in early design stages. In Proceedings of the BS2013 13th Conference of International Building Performance Simulation Association, Chambéry, France, August 26-28 2013; pp. 376-384.

132. Hayter, S.J.; Torcellini, P.A.; Hayter, R.B. The Energy Design Process for Designing and Constructing High-Performance Buildings. CLIMA 2000/Napoli 2001 Word Congress, Naples, Italy, 15-18 September 2001. Available online: https:/ / citeseerx.ist.psu.edu/view doc/download?doi=10.1.1.201.9355\&rep=rep1\&type=pdf (accessed on 12 November 2021).

133. Bambardekar, S.; Poerschke, U. The architect as performer of energy simulation in the early design stage. In Proceedings of the IBPSA 2009 International Building Performance Simulation Association 2009, Glasgow, Scotland, 27-30 July 2009; pp. 1306-1313.

134. Attia, S.; Beltrán, L.; De Herde, A.; Hensen, J. Architect friendly: A comparison of ten different building performance simulation tools. In Proceedings of the IBPSA 2009 International Building Performance Simulation Association 2009, Glasgow, Scotland, 27-30 July 2009; pp. 204-211.

135. Samuelson, H.; Claussnitzer, S.; Goyal, A.; Chen, Y.; Romo-Castillo, A. Parametric energy simulation in early design: High-rise residential buildings in urban contexts. Build. Environ. 2016, 101, 19-31. [CrossRef]

136. Zhang, X.; Zheng, R. Reducing building embodied emissions in the design phase: A comparative study on structural alternatives. J. Clean. Prod. 2020, 243, 118656. [CrossRef]

137. Joe, J.; Choi, W.; Kwak, Y.; Huh, J.H. Optimal design of a multi-story double skin facade. Energy Build. 2014, 76, 143-150. [CrossRef]

138. Trubiano, F. Performance based envelopes: A theory of spatialized skins and the emergence of the integrated design professional. Buildings 2013, 3, 689-712. [CrossRef]

139. Gratia, E.; De Herde, A. Greenhouse effect in double-skin facade. Energy Build. 2007, 39, 199-211. [CrossRef] 
140. Wei, Z.; Falzone, G.; Wang, B.; Thiele, A.; Puerta-Falla, G.; Pilon, L.; Neithalath, N.; Sant, G. The durability of cementitious composites containing microencapsulated phase change materials. Cem. Concr. Compos. 2017, 81, 66-76. [CrossRef]

141. Genovese, A.; Amarasinghe, G.; Glewis, M.; Mainwaring, D.; Shanks, R. Crystallisation, melting, recrystallisation and polymorphism of n-eicosane for application as a phase change material. Thermochim. Acta 443 2006, 443, 235-244. [CrossRef]

142. Schultmann, F.; Sunke, N. Sustainable management of construction projects. In Proceedings of the CIB World Building CongressConstruction and Development, Cape Town, South Africa, 14-17 May 2007; pp. 2428-2440.

143. Ofori, G. The environment: The fourth construction project objective? Constr. Manag. Econ. 1992, 10, 369-395. [CrossRef]

144. IEA. Net Zero by 2050 A Roadmap for the Global Energy Sector; International Energy Agency: Paris, France, 2021 ; p. 222.

145. Menegaki, M.; Damigos, D. A review on current situation and challenges of construction and demolition waste management. Curr. Opin. Green Sustain. Chem. 2018, 13, 8-15. [CrossRef]

146. Kabirifar, K.; Mojtahedi, M.; Wang, C.; Tam, V.W.Y. Construction and demolition waste management contributing factors coupled with reduce, reuse, and recycle strategies for effective waste management: A review. J. Clean. Prod. 2020, 263, 121265. [CrossRef]

147. Bland, A.; Khzouz, M.; Statheros, T.; Gkanas, E.I. PCMs for residential building applications: A short review focused on disadvantages and proposals for future development. Buildings 2017, 7, 78. [CrossRef]

148. Šavija, B. smart crack control in concrete through use of phase change materials (PCMs): A review. Materials 2018, 11, 654 [CrossRef] [PubMed]

149. Farnam, Y.; Krafcik, M.; Liston, L.; Washington, T.; Erk, K.; Tao, B.; Weiss, J. Evaluating the use of phase change materials in concrete pavement to melt ice and snow. J. Mater. Civ. Eng. 2016, 28, 04015161. [CrossRef]

150. Lyu, K.; She, W.; Miao, C.; Chang, H.; Gu, Y. Quantitative characterization of pore morphology in hardened cement paste via SEM-BSE image analysis. Constr. Build. Mater. 2019, 203, 621-632. [CrossRef]

151. Royon, L.; Karim, L.; Bontemps, A. Optimization of PCM embedded in a floor panel developed for thermal management of the lightweight envelope of buildings. Energy Build. 2014, 82, 385-390. [CrossRef]

152. Anupam, B.R.; Sahoo, U.C.; Rath, P. Phase change materials for pavement applications: A review. Constr. Build. Mater. 2020, 247, 118553. [CrossRef]

153. Wu, S.; Yan, T.; Kuai, Z.; Pan, W. Thermal conductivity enhancement on phase change materials for thermal energy storage: A review. Energy Storage Mater. 2020, 25, 251-295. [CrossRef]

154. Lin, S.C.; Al-Kayiem, H.H. Evaluation of copper nanoparticles-Paraffin wax compositions for solar thermal energy storage. Sol. Energy 2016, 132, 267-278. [CrossRef]

155. Li, T.; Lee, J.H.; Wang, R.; Kang, Y.T. Heat transfer characteristics of phase change nanocomposite materials for thermal energy storage application. Int. J. Heat Mass Transf. 2014, 75, 1-11. [CrossRef]

156. Wang, Y.; Li, X.; Miao, W.J.; Jiang, B.; Su, Y.; He, X.; Ma, M.; Strnadel, B. Mechanical and microstructure development of portland cement modified with micro-encapsulated phase change materials. Constr. Build. Mater. 2021, 304, 124652. [CrossRef]

157. Pilehvar, S.; Cao, V.D.; Szczotok, A.M.; Carmona, M.; Valentini, L.; Lanzón, M.; Pamies, R.; Kjøniksen, A.L. Physical and mechanical properties of fly ash and slag geopolymer concrete containing different types of micro-encapsulated phase change materials. Constr. Build. Mater. 2018, 173, 28-39. [CrossRef]

158. Afgan, S.; Bing, C. Scientometric review of international research trends on thermal energy storage cement based composites via integration of phase change materials from 1993 to 2020. Constr. Build. Mater. 2021, 278, 122344. [CrossRef]

159. Huo, J.h.; Peng, Z.g.; Xu, K.; Feng, Q.; Xu, D.y. Novel micro-encapsulated phase change materials with low melting point slurry: Characterization and cementing application. Energy 2019, 186, 115920. [CrossRef]

160. Cunha, S.; Leite, P.; Aguiar, J. Characterization of innovative mortars with direct incorporation of phase change materials. J. Energy Storage 2020, 30, 101439. [CrossRef]

161. Sharma, R.; Pei, J.J.; Jang, J.G. Methods of phase change material deposits in concrete to attain the minimal negative effect on mechanical properties. Proc. Conf. Korean Concr. Soc. 2021, 33, 563-564.

162. Kośny, J. PCM-Enhanced Building Components: An Application of Phase Change Materials in Building Envelopes and Internal Structures; Springer: Manhattan, NY, USA, 2015.

163. ASCE/SEI 7-10. ASCE STANDARD Loads for Buildings; American Society of Civil Engineering: Reston, VA, USA, 2010.

164. Gatscher, J.A.; Bachman, F. Elements of 2012 IBC/ASCE 7-10 Nonstructural Seismic Provisions: Bridging the Implementation Gap. In Proceedings of the 15th World Conference on Earthquake Engineering 2012, Lisbon, Portugal, $24-28$ September 2012.

165. Guterres, A. The Sustainable Development Goals Report 2020; United Nations Intergovermental Organization: New York, NY, USA, 2020. 